\title{
Is Bank Debt Special for the Transmission of Monetary Policy? Evidence from the Stock Market*
}

\author{
Filippo Ippolito \\ Universitat Pompeu Fabra, \\ Ali K. Ozdagli \\ Federal Reserve Bank of Boston \\ Barcelona GSE \& CEPR
}

\author{
Ander Perez ${ }^{\dagger}$ \\ Universitat Pompeu Fabra \& Barcelona GSE
}

September, 2013

\begin{abstract}
We combine existing balance sheet and stock market data with two new datasets to study whether, how much, and why bank lending to firms matters for the transmission of monetary policy. The first new dataset enables us to quantify the bank dependence of firms precisely, as the ratio of bank debt to total assets. We show that a two standard deviation increase in the bank dependence of a firm makes its stock price about $25 \%$ more responsive to monetary policy shocks. We explore the channels through which this effect occurs, and find that the stock prices of bank-dependent firms that borrow from financially weaker banks display a stronger sensitivity to monetary policy shocks. This finding is consistent with the bank lending channel, a theory according to which the strength of bank balance sheets matters for monetary policy transmission. We construct a new database of hedging activities and show that the stock prices of bank-dependent firms that hedge against interest rate risk display a lower sensitivity to monetary policy shocks. This finding is consistent with an interest rate pass-through channel that operates via the direct transmission of policy rates to lending rates associated with the widespread use of floating-rates in bank loans and credit line agreements.
\end{abstract}

Keywords: bank lending channel, monetary policy transmission, firm financial constraints, bank financial health, floating interest rates

JEL classification: G21, G32, E52

* We thank Stefan Pitschner, Miguel Karlo De Jesus and Yifan Yu for excellent research assistance. We are grateful to Jeff Fuhrer, Refet Gurkaynak, Satadru Hore, Anil Kashyap, Alex Levkov, Juan Pablo Nicolini, Dino Palazzo, Daniel Paravisini, Joe Peek, Jose Luis Peydró, Matt Pritsker, Christina Romer, David Romer, Nancy Stokey, Geoff Tootell, Christina Wang, Paul Willen, and audiences in the Boston Fed, UPF, the 2013 NASM of the Econometric Society, the 2013 Meeting of Society of Economic Dynamics, the 2013 NBER Summer Institute in Corporate Finance, the 2013 NBER Summer Institute in Monetary Economics, the 2013 Gerzensee ESSFM and the Barcelona GSE "II Asset Prices and the Business Cycle Workshop" for helpful comments. All remaining errors are our own.

$\dagger$ Corresponding author. Department of Economics and Business, Universitat Pompeu Fabra. Ramon Trias Fargas, 25-27. 08005 Barcelona (Spain). Tel: (+34) 93542 1180. Email: ander.perez@upf.edu 


\section{Introduction}

While there is ample evidence of the importance of monetary policy for real investment, consumption, the valuation of financial assets, and more generally for aggregate economic performance, there is still no consensus on the precise channels through which interest rate decisions of central banks bear implications for the real economy. ${ }^{1}$ An important strand of the finance and macroeconomics literature has been devoted to the exploration of the role of financial intermediaries in these channels, given their pre-eminent role in the implementation of monetary policy and in the intermediation of aggregate savings. ${ }^{2}$ Many of the empirical studies in this literature use variation across firms as a source of evidence, and their main challenge lies in the identification of the degree of bank dependence of individual firms.

This paper contributes to our understanding of the importance of financial intermediaries for the transmission of monetary policy by studying whether the stock prices of bankdependent firms are relatively more responsive to monetary policy shocks. We pursue this goal by employing a new, direct measure of bank dependence, computed as the ratio of a firm's bank debt to its total assets, for publicly-listed U.S. firms between 2003 and 2008. Furthermore, our measure of bank dependence, combined with data on bank financial health, bank-firm linkages, firm financial constraints, and a novel database on interest-rate hedging activities, allows us to provide evidence on the channels through which a bank-centered transmission mechanism might operate.

We find that stock prices of bank-dependent firms react more strongly to monetary policy shock surprises. In particular, the stock price of a firm with a two standard deviation higher value of our bank dependence measure decreases by about 1 percent more in response to a 1 percentage point surprise increase in the federal funds rate. To put this effect into

\footnotetext{
${ }^{1}$ Examples are Gertler and Gilchrist (1994), Angeloni, Kashyap, and Mojon (2003), Bernanke and Kuttner (2005), and Boivin and Giannoni (2006).

${ }^{2}$ Examples are Bernanke and Blinder (1988, 1992), Stein (1998), Kashyap and Stein (2000), Kishan and Opiela (2000), Van den Heuvel (2002), and Bolton and Freixas (2006).
} 
perspective, we find that a firm's stock price decreases by about 4 percent on average in response to a 1 percentage point surprise increase in the federal funds rate, meaning that a two standard deviation greater bank dependence strengthens the effect of monetary policy on stock prices by around $25 \%$. This result is robust to controlling for firms' leverage, financial constraints, debt maturity, interest sensitivity of operating profits, and asset pricing risk factors. We also confirm the robustness of our results using an endogeneity test guided by asset pricing theory and an analysis of the firm characteristics that drive bank debt usage.

We explore two channels through which bank dependence might influence the sensitivity of stock prices to monetary policy. The first channel, which is typically referred to as the bank lending channel, is based on theories arguing that financial frictions faced by banks amplify the impact of monetary policy shocks. ${ }^{3}$ These theories rely on some failure of the Modigliani-Miller theorem for banks, in the sense that the supply of credit by banks is affected by variations in the strength of their balance sheet, which itself might depend on the stance of monetary policy. ${ }^{4}$

An implicit assumption of the bank lending channel is that some firms are not able to substitute their banking relationships with alternative sources of financing at a low cost. ${ }^{5}$ Therefore, we first provide evidence that bank dependence affects the sensitivity of stock returns to monetary policy surprises more strongly for unrated and young firms, which are more likely to have limited access to alternative sources of finance.

To test for the existence of a bank lending channel, we follow Kashyap and Stein (2000), Kishan and Opiela (2000) and Jimenez, Ongena, Peydró and Saurina (2012) and use bank size and the bank capital ratio as measures of bank financial health. We find that bank-dependent

\footnotetext{
${ }^{3}$ For alternative theories of why banks' financial frictions matter, see Bernanke and Blinder (1988), Bernanke and Gertler (1995), Stein (1998), and Bolton and Freixas (2006), amongst others.

${ }^{4}$ Kashyap and Stein (2000), Kishan and Opiela (2000), and Jimenez, Ongena, Peydró and Saurina (2012) provide empirical evidence that financially fragile financial intermediaries reduce their supply of loans relatively more following a tightening of monetary policy.

${ }^{5}$ For evidence on this point see Kang and Stulz (2000), Khwaja and Mian (2008), Paravisini (2008), Chava and Purnanandam (2011), and Chodorow-Reich (2013).
} 
firms that borrow from banks with weaker balance sheets display a stronger sensitivity to monetary policy shocks, which is consistent with the prediction of the bank lending channel. Moreover, this relation is stronger for unrated and young firms. We address the potential endogeneity in firm-bank relationships by investigating which firm characteristics are relevant for the match between firms and banks. Additionally, we instrument for bank financial health using the instrumental variables approach proposed by Ashcraft (2008), Berger et. al. (2005) and Berger and Bouwman (2013). Both approaches confirm the robustness of our results.

We examine a second channel by which bank lending to firms can be special for the transmission of monetary policy. This second channel is based on the widespread use of floating-rate agreements in bank loans and the prevalence of fixed-rate agreements in nonbank liabilities. As monetary policy changes have a direct impact on the reference rates used in the floating-rate agreements, we expect these changes to be reflected mechanically into the cost of existing bank loans for firms. This suggests that bank debt might be special for the transmission of monetary policy because for bank-dependent firms a variation in federal funds rates is more likely to affect interest rate expenses and therefore profits. We call this channel the interest rate pass-through channel. In the presence of financing frictions, the impact of this channel could be amplified by the effect that higher interest expenses have on the firm's liquidity position and net worth.

We test the interest rate pass-through channel by exploiting the fact that many firms hedge against interest rate risk by converting their floating-rate liabilities to fixed-rate liabilities through the use of interest-rate swaps and other derivative contracts. In particular, we collect data from annual 10-K Securities and Exchange Commission (SEC) filings using a text search (parsing) algorithm to identify which firms engage in interest rate hedging. Our results show that bank-dependent firms that hedge against interest rate risk display a lower sensitivity to monetary policy shocks. We provide further evidence on the interest rate pass-through channel by showing that for bank-dependent firms the sensitivity of interest 
rate expenses to changes in monetary policy is lower if firms hedge. Taken together, these results are consistent with a channel that operates through a direct pass-through of policy rates to loan rates for a majority of bank debt users.

Overall, our results suggest that bank lending to firms plays an important role in the transmission of monetary policy, and that there is significant heterogeneity across bankdependent firms in their reaction to monetary policy shocks. In particular, the sensitivity of stock prices to monetary policy changes is affected by the extent to which a firm uses interest rate hedging, borrows from a financially healthy bank, or has access to other sources of debt financing besides bank borrowing. Our study is important not only for academic economists and policy makers who are interested in the real effects of the monetary policy, but also for investors who are interested in the exposure of their stock market portfolios to monetary policy shocks.

The results of our paper are relevant for several strands of the macroeconomics and finance literatures. They contribute to the literature that has studied the cross-sectional heterogeneity in the reaction of firms to monetary policy shocks. Gertler and Gilchrist (1994) show that following a monetary policy contraction, small firms' short-term borrowing declines, while large firms' borrowing expands. Furthermore, the performance of small firms, measured by sales and inventories, deteriorates much more than that of large firms. While this evidence is consistent with a bank lending channel because small firms are more likely to be bank-dependent, it is also consistent with a broader credit channel in which monetary policy contractions affect the general availability of external finance more for small firms. Ehrmann and Fratzscher (2004) find that the stock prices of small, poorly rated, low cash flow and high Tobin's q firms in the S\&P500 are relatively more responsive to monetary policy. Our paper contributes to this literature by employing a direct measure of bank dependence, computed as the ratio of a firm's bank debt to its total assets, that enables us to measure bank dependence precisely and to make statements about the quantitative 
importance of monetary policy transmission mechanisms that operate through bank lending. Furthermore, we also analyze the heterogeneous effects of monetary policy within the sample of bank-dependent firms and identify the factors that drive this heterogeneity.

Several theories have been put forward to explain why financing frictions that affect banks may influence the transmission of monetary policy to the real economy. In each theory, monetary policy has an effect on banks' cost of funds beyond the effect of the change in the risk-free rate, leading to an additional response in the supply of intermediated credit (Bernanke and Blinder [1988], Bernanke and Gertler [1995], Stein [1998], Van den Heuvel [2002], and Bolton and Freixas [2006]). In parallel, empirical work has tested the main prediction of these theories, in particular, whether financially fragile financial intermediaries contract their supply of loans relatively more following a tightening of monetary policy. Bernanke and Blinder (1992) find that a tightening of monetary policy leads to a decline in aggregate bank lending activity, and later studies have found that this impact is stronger for small, less liquid and more leveraged banks (Kashyap and Stein [2000], Kishan and Opiela [2000], and Jimenez, Ongena, Peydró and Saurina [2012]), and for banks that are not affiliated with multibank holding companies (Ashcraft [2006]). Nevertheless, finding a relationship between monetary policy shocks and bank loan supply related to financing frictions at the bank level is a necessary but not sufficient condition for an operative bank lending channel. It must be also, as our evidence suggests, that firms are unable to costlessly replace bank loans with other nonbank sources of finance. Our paper thus contributes to this literature by evaluating how the financial health of a bank ultimately affects the response of its borrowers to monetary policy shocks.

Addressing the importance of bank dependence, several papers have explored exogenous shocks to bank capital, such as foreign sector shocks, political events or government policy changes, and have found that these shocks affect investment spending, capital structure or performance of their borrowers significantly (Peek and Rosengren [2000], Kang and Stulz 
[2000], Khwaja and Mian [2008], Paravisini [2008], and Chava and Purnanandam [2011]). Our results suggest that monetary policy shocks are also able to produce a sufficiently large impact on banks' balance sheet strength so that bank financial health plays an important role in the transmission of monetary policy.

Finally, most of the previous papers measure firms' reaction to shocks in bank loan supply using balance sheet variables such as capital expenditures, investment or variations in bank debt. While informative, these studies might suffer from the problem that these variables are measured a long time after the bank capital shock or monetary policy event occurred, a time during which other shocks and indirect mechanisms might come into play. Most closely

related to our paper in this aspect are those studies focusing on the stock price reaction to bank lending supply shocks (Ongena, Smith and Michalsen [2003], Giannetti and Simonov [2011], and Carvalho, Ferreira and Matos [2010]), none of which study bank lending supply shocks driven by monetary policy actions.

\section{Data Description and Summary Statistics}

\subsection{Firm-level data}

Our sample consists of U.S. firms covered by Capital IQ (CIQ), CRSP and Compustat from 2003 to 2008, excluding utilities (SIC codes 4900-4949) and financials (SIC codes 60006999). We focus on this period because we do not have wide coverage of bank debt data before 2003 and there is no widely accepted measure of monetary policy shocks after the federal funds target rate hit the zero lower bound in June 2008. We remove firm-year observations with negative revenues, missing information on total assets, or a value of total assets under $\$ 10$ million. We also discard penny stocks, defined as those with a price of less than $\$ 5$ as in Amihud (2002). After the above filters, the sample contains 21,745 firmyear observations comprising 4,408 unique firms. Exact variable definitions are given in the 
appendix. Following the common practice in corporate finance literature, all variables are winsorized at the $1 \%$ level in both tails of the distribution to prevent extreme values from overinfluencing our regressions. ${ }^{6}$ Total assets are expressed in terms of year-2000 dollars. Throughout the analysis, we use demeaned firm-level variables for the purpose of facilitating the interpretation of the coefficient estimates in the regressions with interaction terms.

CIQ compiles detailed information on capital and debt structure from the footnotes of 10-K SEC filings. In particular, from CIQ we obtain data on the amount of bank debt firms have in their liabilities. Our main measure of bank dependence, BankDebt/At, is defined as total bank debt, defined as credit lines (CL) plus term loans (TL), divided by the total value of book assets (Compustat item 6). CIQ also reports the amount of undrawn credit lines. Therefore, we also employ a second measure of bank dependence computed as CL plus TL plus undrawn credit lines, divided by the total value of book assets.

Table I provides key statistics for the balance sheet variables that we employ in our study. Across the entire sample (column 1), bank debt represents on average $5.11 \%$ of the book value of assets and $36.34 \%$ of total debt. For the subset of firms with some bank debt (column 2), the above ratios rise to $12.77 \%$ and $57.01 \%$. In both samples, approximately half of bank borrowings are in the form of drawn credit lines and the other half are term loans. ${ }^{7}$

\section{[TABLE I ABOUT HERE]}

A comparison between columns 2 and 4 reveals that firms with bank debt are of similar size as leveraged firms without bank debt, but are more profitable, more likely to be rated and more leveraged. Bank debt users are more likely to use floating-rate debt, which represents $10.80 \%$ of the value of their assets, compared to $2.04 \%$ for nonbank debt users. According to Chernenko and Faulkender (2011), the percentage of floating-rate debt represents $41.57 \%$ of

\footnotetext{
${ }^{6}$ See, for example, Fama and French (1992) and Sufi (2009).

${ }^{7}$ The large dependence on bank debt reported in column 2 confirms previous findings on specialization in debt instruments previously examined in Colla, Ippolito and Li (2013).
} 
total long-term debt reported in 10-K SEC filings over the period 1993-2003. In our sample, which covers a different set of years, the percentage of floating-rate debt in total debt is $32.71 \%$ for the entire sample, and $44.82 \%$ for the sample of bank debt users.

Figure 1 explores in more detail the relation between bank debt and floating-rate debt. Firm-year observations are grouped into deciles of bank debt as a percentage of total debt. On the vertical axis, we report floating-rate debt as a percentage of total debt. The figure shows a striking correlation between bank debt and floating-rate debt. For those firms for which the entire stock of debt consists of bank debt, more than $70 \%$ of it is floating-rate. For those firms whose debt is entirely from nonbank sources, however, only around $10 \%$ of debt is floating-rate. These figures confirm the findings of Faulkender (2005) according to which $89.9 \%$ of bank loans are issued with a floating-rate, compared to only $7 \%$ of floating-rate bonds.

[FIGURE 1 ABOUT HERE]

\subsection{Bank-firm matching and bank level data}

We calculate the exposure of each firm to the financial health of its lenders as the weighted average of current financial health of the banks a firm has borrowed from in the previous five years. We use syndicated loans and measure the weights as the amount lent by each bank as a share of total lending to the firm during those five years. The construction of this variable proceeds in three steps. First, we calculate a firm-bank-year variable for the volume of new lending each year from each bank to each firm, using the Loan Pricing Corporation's Dealscan database. Dealscan reports the total amounts for all loans, but only reports the allocations to each bank in the syndicate for around one third of the observations. For this reason, we estimate a model of bank allocations as a function of the status of the bank as lead lender or participant, the number of lead banks, and the number of participant banks. For 
consistency, once we have estimated the model, we apply the estimates to all observations, including the ones for which we have data. ${ }^{8}$ Second, we calculate for each firm, year and bank the share that the bank has in all of the lending done in the previous five years (not including the current year), and this share is calculated using the estimated allocations and the total loan amounts. ${ }^{9}$

Third, we multiply the exposure variable by the financial health of the bank to construct a firm-year variable that captures the weighted average health of the banks that a firm has been borrowing from in recent years. To obtain these measures of bank financial health for U.S. banks, we use Call Report information contained in the quarterly Consolidated Financial Statements (form FR Y-9C) for Bank Holding Companies (BHC). These reports have to be filed with the Federal Reserve by all U.S. bank holding companies with total consolidated assets of $\$ 500$ million or more. For banks not domiciled in the United States, we use the Bankscope database, in which we identify bank holding companies. We match the Dealscan database to the Call Report and Bankscope data by tracing owner-subsidiary relationships manually.

Our bank financial health proxies are bank size and capital ratio. Bank size is measured as total assets (Call Report item bhck2170, Bankscope item data 2025), expressed in terms of year-2000 dollars. Capital ratio is measured as tier 1 capital divided by total risk-weighted assets (Call Report item bhck8274 divided by item bhcka223, Bankscope item data 18150).

\subsection{Interest Rate Hedging Data}

We collect data on interest rate hedging activities of U.S. firms using a text-search algorithm that scans 10-K corporate filings with the SEC. Disclosure of derivative hedging is

\footnotetext{
${ }^{8}$ The model provides a good fit for the sample for which we have lending allocations. The $R^{2}$ of the regression explaining the allocation of lead lenders using the number of leads and the number of participant banks as explanatory variables is $34 \%$.

${ }^{9}$ Our strategy to match banks to firms is supported by the evidence in Chodorow-Reich (2013), who shows that lending relationships are persistent.
} 
mandatory under the 1998 Financial Reporting Release (FRR) No. 48 of the SEC and the 2001 SFAS No. 133. We do a detailed search of multiple phrases consistent with usage of interest rate derivatives (such as "hedge against interest rate", "hedge interest rate", "interest rate swap"), and then, for those filings for which we have a preliminary reading consistent with interest rate hedging, we check for false positives by controlling for negations, such as "not use any interest-rate swaps", "not use interest-rate swaps", "not currently use any interest-rate swaps", "not hedge interest rate", "not use derivative financial instruments as a hedge against interest rate", "termination of interest rate swap", "fixed to floating interest rate swap", or "do not currently use interest rate swap".

The following two paragraphs are examples of the type of discussion on hedging activities that we find in the 10-K files. In fiscal year 2008, BioFuel Energy Corp reports that:

We are subject to interest rate risk in connection with our bank facility. Under the facility, our bank borrowings bear interest at a floating-rate based, at our option, on LIBOR or an alternate base rate. (...). In September 2007, the Operating Company, through its subsidiaries, entered into an interest rate swap for a two-year period. The contract is for $\$ 60.0$ million principal with a fixed interest rate of $4.65 \%$, payable by the Operating Company and the variable interest rate, the one-month LIBOR, payable by the third party.

Similarly, in fiscal year 2006 Netsmart Technologies reports:

In October 2005, we entered into a revolving credit and term loan agreement with the Bank of America (...). This financing provides us with a five-year term loan of $\$ 2.5$ million. The term loan bears interest at LIBOR plus $2.25 \%$. We have entered into an interest rate swap agreement with the Bank for the amount outstanding under the term loan whereby we converted our variable rate on the 
term loan to a fixed rate of $7.1 \%$ in order to reduce the interest rate risk associated with these borrowings.

\subsection{Monetary Policy Data}

Because the equity market will have already responded to anticipated policy actions, we follow the approach of Kuttner (2001) and Bernanke and Kuttner (2005) to dissect the monetary policy actions into the unexpected (surprise) component and the anticipated (expected) component. The identification of the surprise element in the target rate change relies on the price of the current month 30-day federal funds futures contracts, a price which encompasses market expectations of the effective federal funds rate. We follow this method because federal funds futures outperform target rate forecasts based on other financial market instruments or based on alternative methods, such as sophisticated time series specifications and monetary policy rules. ${ }^{10}$ Another advantage of looking at one-day changes in near-dated federal funds futures is that federal funds futures do not exhibit predictable time-varying risk premia (and forecast errors) over daily frequencies. ${ }^{11}$

Following Bernanke and Kuttner's analysis, we define an event as either an FOMC meeting or an announced change in the funds target rate. Kuttner (2001) and Bernanke and Kuttner (2005) obtain the corresponding surprise change in the target rate by first calculating the change in the rate implied by the corresponding futures contract, given by 100 minus the futures contract price, and then scaling this result by a factor associated with the number of days of the month in which the event occurred because the payoff of the contract is determined by the average realized federal funds effective rate during the month. Accordingly, the unexpected target rate change, for an event taking place on day $d$ of month

\footnotetext{
${ }^{10}$ See Evans (1998) and Gürkaynak, Sack and Swanson (2007) for details.

${ }^{11}$ See, for example, Piazzesi and Swanson (2008).
} 
$m$, is given by

$$
\Delta i^{u}=\frac{D}{D-d}\left(f_{m, d}^{0}-f_{m, d-1}^{0}\right),
$$

where $f_{m, d}^{0}-f_{m, d-1}^{0}$ is the change in the current-month implied futures rate, and $D$ is the number of days in the month. To suppress the end-of-month noise in the federal funds rate, the unscaled change in the implied futures rate is used as the measure of target rate surprise when the event occurs on the last three days of a month. If the event happens on the first day of a month, $f_{m-1, D}^{1}$ is used instead of $f_{m, d-1}^{0}$. The expected federal funds rate change is defined as the difference between the actual change minus the surprise:

$$
\Delta i^{e}=\Delta i-\Delta i^{u}
$$

where $\Delta i$ is the actual federal funds rate change. The data for the decomposition of the federal funds target rate changes can be obtained from Kenneth Kuttner's webpage. ${ }^{12}$

\subsection{The Reaction of Equity Prices to Changes in the Target Fed- eral Funds Rate}

In this section, we compare the reaction of stock prices to monetary policy shocks in our sample and the CRSP universe. We start with the reaction of the aggregate CRSP valueweighted index between February 1994 and June 2008. Following Rigobon and Sack (2005), we focus on this period for two reasons. First, starting in February 1994, the FOMC's policy of announcing target rate changes at pre-scheduled dates virtually eliminated the timing ambiguity associated with rate changes prior to this time period. Second, after June 2008, the Federal Reserve switched from announcing a specific target rate to announcing a range for the target rate.

\footnotetext{
${ }^{12} \mathrm{http}: / /$ econ.williams.edu/people/knk1/research
} 
Following Bernanke and Kuttner (2005), we use the CRSP value-weighted index in order to identify outliers, defined as those event dates at which Cook's D-statistic exceeds 0.1. We drop these outliers from our analysis. Our list of outliers for the 1994-2002 period matches those in Bernanke and Kuttner (2005), that is, October 15, 1998, January 3, 2001, March 20, 2001, April 18, 2001, and September 17, 2001 which have been discussed in their paper in detail. We also identify two additional outliers for the post-2002 period, January 22, 2008, and March 18, 2008, both of which are characterized by very large rate cuts. On January 21, 2008, in response to deteriorating market conditions, the Federal Open Market Committee (FOMC) held an unscheduled meeting (conference call) despite the national holiday (Martin Luther King day). They decided on a rate cut of 75 basis points, which they announced shortly before the opening of U.S. markets. Although the rate cut was almost entirely unexpected, with an unprecedented surprise of -74 basis points, stock prices declined by almost 100 basis points compared to their closing price before the holidays. Shortly after, on March 18, 2008, the FOMC announced another unusually large cut of the federal funds rate $(-75$ basis points) in response to turmoil in the markets and the collapse of Bear Stearns. Stocks rallied in response, although the federal funds futures data suggested that some market participants expected an even larger rate cut (about 100 basis points).

Table II offers a comparison between the responses of equity prices to federal funds rate changes in different samples. Columns 1 and 2 show that on the day of an FOMC announcement, a 100 basis points surprise increase in the federal funds rate decreases stock prices by around 300 basis points when we look either at the value-weighted returns or the individual returns of the entire CRSP universe between 1994 and 2008. This result is comparable to the numbers reported in Bernanke and Kuttner (2005). Columns 3 and 4 show that the reaction of equity prices to surprise changes in monetary policy is stronger in the sample of 2003-2008 than in previous years. However, the sign and significance of the coefficient of surprise is the same for both samples. A comparison of columns 4 and 5 
reveals that the sample of firms for which we have our bank dependence data has a reaction to monetary policy shocks very similar to that of the overall CRSP universe during the 2003-2008 period.

[TABLE II ABOUT HERE]

\section{Is Bank Debt Special for the Transmission of Mone- tary Policy?}

\subsection{Motivation of Empirical Predictions and Empirical Strategy}

In this section, we explore whether bank lending to firms is special for the transmission of monetary policy. We start by analyzing whether a firms' stock price change $\operatorname{Ret}_{i, t}$ on the day $t$ in which a monetary policy shock Surprise $_{t}$ occurs depends on the importance of bank debt as a source of financing, $(B a n k D e b t / A t)_{i, t-1}$. Formally, we test whether

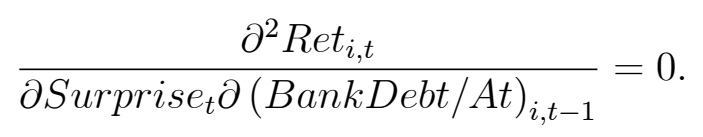

This is equivalent to testing whether $\beta_{3}=0$ in the following empirical specification:

$$
\begin{aligned}
\text { Ret }_{i, t}= & \beta_{0}+\beta_{1} \text { Surprise }_{t}+\beta_{2}\left(\text { BankDebt } / A t_{i, t-1}\right. \\
& +\beta_{3} \text { Surprise }_{t} *\left({\text { BankDebt } / A t)_{i, t-1}}\right. \\
& +\gamma \text { Controls }_{i, t-1}+\lambda \text { Surprise }_{t} * \text { Controls }_{i, t-1}+\varepsilon_{i, t},
\end{aligned}
$$

where Controls $_{i, t-1}$ is a vector of firm characteristics. ${ }^{13}$ We use the last fiscal year-end data

\footnotetext{
${ }^{13}$ Our objective at this stage is to test whether $\beta_{3}$ is significantly different from zero, which would indicate that bank debt is special for the transmission of monetary policy. Even though most theories, as will be discussed later, predict that bank-dependent firms are more reactive to monetary policy $\left(\beta_{3}<0\right)$, one could
} 
available before the date of the monetary policy event in order to capture the information available to investors at the time of the monetary policy announcement, in line with most of the cross-sectional asset pricing literature dating back at least to Fama and French (1992). ${ }^{14}$

Our firm-level controls include book leverage, firm size, market-to-book ratios, profitability, and interest rate sensitivity, which are described in Table A1 in detail. We control for book leverage because bank-dependent firms are more likely to be highly leveraged, and as such might be more sensitive to monetary policy. We control for firm size and marketto-book ratios because these variables are well-known risk factors for asset prices since the seminal paper of Fama and French (1992), and they can also affect the reaction of stock prices to policy surprises because they are related with financial constraints and investment opportunities. ${ }^{15}$ Profitability is included because as shown in Fama and French (1995), the market-to-book ratio is associated with persistent differences in profitability and firms with bank debt tend to be more profitable, as shown in Table I. Also, Ehrmann and Fratzscher (2004) report strong evidence that firms with low profitability are more responsive to monetary policy when profitability is measured as cash flow divided by income. Finally, we control for the interest rate sensitivity of operating profits because it might influence the propensity to borrow from banks. This would generate a correlation between bank dependence and the reaction of stock prices to monetary policy even if there were no causal relationship between these variables. ${ }^{16}$

also suggest plausible and empirically motivated theories that would predict the opposite based on the idea that bank-firm relationships enable firms to benefit from some degree of insurance provided by their lenders against changes in credit availability.

${ }^{14}$ With a slight abuse of notation, for firm characteristics $t-1$ refers to the most recent fiscal-year end prior to the federal funds rate target announcement date. For Surprise and Ret, $t$ refers to the monetary policy announcement date, of which there are many in any given year.

${ }^{15}$ We also add CAPM betas, calculated as in Fama and French (1992), as an additional control in some specifications. Alternatively, we could use Fama-French factors based on these risk characteristics (size, market-to-book, beta) to calculate returns not explained by these factors. We prefer our approach because firm characteristics subsume the effect of the Fama-French risk factors. See, for example, Daniel and Titman (1997) and Ferson and Harvey (1999).

${ }^{16}$ Our particular concern is that bank-dependent firms are special in that they are on average riskier and more interest rate sensitive, which would suggest that we overestimate the direct impact of bank debt. While interest rate sensitivity of operating profits should address these concerns, we look deeper into the 


\subsection{Empirical Results}

Table III presents the results of regression (1) using alternative specifications that become more restrictive across columns. The first column of Table III contains the result from a basic random effects panel regression with no controls and suggests that a two standard deviation (0.21) increase in our bank dependence measure causes the stock price to increase $1.04(=-4.955 \times 0.21)$ percentage points more in response to a 1 percentage point surprise decrease in the federal funds rate. To put this effect in perspective, the same surprise decrease in the federal funds rate causes the stock price of the firm with the average amount of bank debt over assets $(5.11 \%)$ to increase about $4.23 \%$ on average.

In order to address potential identification issues, such as non-spherical disturbances and omitted variables, we progressively add controls, industry fixed-effects, both interacted and uninteracted, standard errors clustered at the event-industry level, and finally firm fixed-effects both interacted and uninteracted. Non-sphericality would primarily affect the standard errors of our estimates rather than their consistency, which is the main reason why we use clustered errors. However, omitted variables can influence our inference by affecting both the standard errors and the consistency of our estimates. Therefore, controls and firmlevel fixed-effects specifications aim at differentiating between bank debt being special or bank-dependent firms being special for reasons that are not captured in our basic regression in column 1 of Table III.

Column 2 introduces firm controls and year fixed-effects, which leads to a significant increase in the estimate of $\beta_{3}$. This increase seems to be robust to alternative specifications, as shown in columns 3 to $8 .{ }^{17}$ In column 3 , industry fixed-effects enter the regression

relationship between a firm's riskiness and its bank financing behavior in Table A3. Contrary to our concerns, columns 1-3 show that bank debt usage is negatively associated with alternative measures of risk, such as interest rate sensitivity of operating profits (insignificant), cash flow volatility and CAPM beta.

${ }^{17}$ Table A2 in the appendix examines the coefficients of the interaction between surprise and firm characteristics across different sample periods. Some coefficients, such as the market-to-book ratio or size appear very stable over time, while the sign of those on profitability or leverage change over time. 
both interacted with surprise and uninteracted, with industries classified according to FamaFrench 48 sectors available from Kenneth French's website. Column 4 adds error clustering at the event-industry level to address possible time-and-cross-section heteroskedasticity in the errors. Column 5 extends the definition of bank debt to include undrawn credit lines. Column 6 includes interest rate sensitivity, measured as in Faulkender (2005) as the correlation between quarterly firm EBITDA and three-month average LIBOR rates, cash flow volatility, and CAPM beta as additional controls. Column 7 replaces industry fixed-effects with firm fixed-effects. Finally, for completeness, column 8 includes fixed-effects interacted with surprise. $^{18}$ Overall, we find significant evidence that bank-dependent firms are more responsive to monetary policy shocks.

Although our specifications include controls that might potentially explain the reaction of stock prices to monetary policy, it is possible that we have omitted some other variables that might affect the reaction of stock prices to monetary policy shocks and that are also correlated with our bank dependence measure. ${ }^{19}$ Asset pricing theory offers us a solution to this apparent problem and allows us to use the standard Hausman test to compare the random effects and fixed-effects models to test whether omitted variables are a source of concern. If there is an omitted variable problem as suggested above, then asset pricing theory tells us that we should expect this variable to affect both a stock's responsiveness to monetary policy shocks and its expected returns. In particular, if a variable makes a stock more responsive to any macroeconomic shock priced by investors, this variable should directly affect the expected return the investors are willing to accept in order to take on the risk associated with that shock. In our context, because monetary policy affects the consumption-savings decisions of investors, it is reasonable to assume that the exposure of a

\footnotetext{
${ }^{18}$ To perform the interacted fixed effects estimation of column 8 we resort to standard OLS and the FrischWaugh-Lovell theorem, which allows us to reduce the computation time significantly by reducing the number of control variables

${ }^{19}$ Because monetary policy surprises are exogenous, our estimator is still consistent if there are omitted variables that are correlated with our bank-dependence measure but do not affect the responsiveness of stock prices to monetary policy shocks. See Nizalova et al. (2012).
} 
stock to monetary policy shocks is priced by investors. Hence, any variable that makes the stock more responsive to monetary policy should directly affect firms' expected returns.

As a result, asset pricing theory tells us that the omitted variable issue should create a bias not only in the coefficient of bank dependence interacted with the policy surprise, but also in the coefficient of bank dependence. Therefore, we can safely argue that the former coefficient, the one we are interested in, is free from the omitted variable bias if we can show that the latter coefficient does not suffer from omitted variable bias. We can test this second hypothesis using the standard Hausman test to compare the random effects (column 2) and fixed-effects models (column 7). We find that the coefficient of our uninteracted bank dependence measure is 0.36 in the fixed-effects model versus 0.33 in the random effects model and the difference is statistically insignificant with a $t$-statistic of 0.3 . Therefore, we find evidence that bank-dependent firms are more responsive to monetary policy shocks not because bank-dependent firms are special, but because bank debt is special in the transmission of monetary policy shocks. The Hausman test provides qualitatively

similar results when we compare the random effects model in column 2 with the setting where firm fixed-effects are interacted with surprise (column 8), although the estimated coefficient of interest is somewhat larger, -9.71 vs. -6.76 , with a $t$-statistic of 0.77 .

\section{[TABLE III ABOUT HERE]}

\subsection{Robustness: Short-Term Debt}

A possible concern in Table III is that bank debt may be proxying for the use of short-term debt. This concern finds support in the descriptive statistics reported in Table I, according to which bank debt users have a higher percentage of short-term debt than nonbank-debt 
users $(4.14 \%$ versus $0.87 \%$, calculated as a share of total assets). For example, to the extent that changes in monetary policy affect primarily the short end of the yield curve, one can expect firms with a shorter average maturity of debt to be more sensitive to increases in interest rates.

To test this hypothesis, we rewrite the specification provided in equation (1) in terms of short-term debt divided by the book value of assets, STDebt/At. Formally, the complete regression specification is:

$$
\begin{aligned}
& \operatorname{Ret}_{i, t}=\beta_{0}+\beta_{1} \text { Surprise }_{t}+\beta_{2}\left(\text { BankDebt } / A t_{i, t-1}+\beta_{3}(\text { STDebt } / A t)_{i, t-1}\right. \\
& +\beta_{4} \text { Surprise }_{t} *\left(\text { BankDebt } / A t_{i, t-1}+\beta_{5} \text { Surprise }_{t} *(\text { STDebt } / A t)_{i, t-1}\right. \\
& +\gamma \text { Controls }_{i, t-1}+\lambda \text { Surprise }_{t} * \text { Controls }_{i, t-1}+\varepsilon_{i, t},
\end{aligned}
$$

Table IV provides the empirical results of this test. Columns 1 and 2 show the results of a version of regression (2) in which the terms containing (BankDebt/At $)_{i, t-1}$ are removed. We observe that the amount of short-term debt in a firm's balance sheet is not significantly associated with the strength of the sensitivity to surprises in the federal funds rate. Columns 3 and 4 provide a complete specification of (2), including bank debt, both interacted with surprise and non-interacted. ${ }^{20}$ The coefficient $\beta_{5}$ becomes significant and positive in most specifications, while the coefficient $\beta_{4}$ retains the sign, size and significance of the specifications reported in Table III. In columns 5 and 6 , we add a triple interaction term Surprise S $\left(\right.$ BankDebt $/ A t_{i, t-1} *(S T \text { Debt } / A t)_{i, t-1}$ to measure if bank debt is relatively more special when it is short-term, and find no significant evidence consistent with this conjecture. ${ }^{21}$ We conclude that the higher sensitivity of bank debt users to federal funds rate surprises is not due to their higher exposure to short-term debt.

\footnotetext{
${ }^{20}$ The Pearson pair-wise correlation between these two variables is 0.267 .

${ }^{21}$ In this regression specification we also add the associated second order term $(\text { BankDebt/At })_{i, t-1} *$ $(\text { STDebt/Assets })_{i, t-1}$.
} 
[TABLE IV ABOUT HERE]

\section{Why is Bank Debt Special? (I) The Bank Lending Channel}

The results obtained in Section 3 suggest that bank debt is special for the transmission of monetary policy, and our next task is to understand why this may be so. Our results show that bank debt is special in that firms that use bank debt are more sensitive to monetary policy shifts. We focus on two mechanisms that predict a stronger sensitivity to monetary policy: the bank lending channel, which we analyze in this section, and the interest rate pass-through channel, which will be discussed in Section 5 .

\subsection{Motivation of Empirical Predictions and Empirical Strategy}

The bank lending channel is a mechanism according to which monetary policy shocks are amplified by the financial frictions that affect banks (Bernanke and Blinder [1988], Bernanke and Gertler [1995], Stein [1998], and Bolton and Freixas [2006]). This channel relies on the failure of the Modigliani-Miller theorem for the capital structure of banks, in the sense that the supply of credit by banks is affected by the strength of their balance sheet, which itself varies with monetary policy. Bernanke and Blinder (1992), Kashyap and Stein (1995), Kashyap and Stein (2000), Kishan and Opiela (2000), and Jimenez, Ongena, Peydró and Saurina (2012) provide empirical evidence that financially fragile intermediaries reduce their supply of loans relatively more than peers with stronger balance sheets following a tightening of monetary policy.

We start our analysis by studying whether bank-dependent firms that suffer from fi- 
nancing constraints are relatively more reactive to monetary policy shifts; in other words, whether

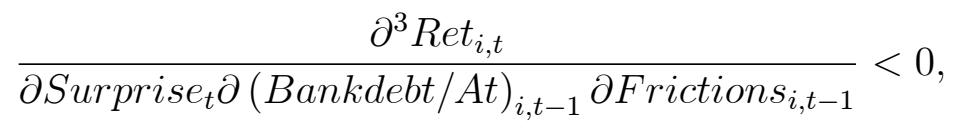

where Friction $s_{i, t-1}$ is a measure of a firm's financing constraints, such that $\partial$ Frictions $_{i, t-1}>$ 0 captures a worsening of financing frictions. This analysis is motivated by the intuition that the bank lending channel should be stronger if bank borrowers find it relatively difficult to switch lenders. $^{22}$ For a given level of bank dependence (as measured by bank usage), financing frictions can capture the potential heterogeneity across firms in their inability to substitute bank debt with alternative sources of financing. We use firm size, age, and credit rating as proxies for financing frictions, following the existing literature (Almeida, Campello, and Weisbach [2004], and Hadlock and Pierce [2013]). The specification we use for this test is

$$
\begin{aligned}
\text { Ret }_{i, t}= & \beta_{0}+\beta_{1} \text { Surprise }_{t}+\beta_{2}\left({\text { Bankdebt } / \text { At })_{i, t-1}+\beta_{3} \text { Frictions }_{i, t-1}}\right. \\
& +\beta_{4} \text { Surprise }_{t} * \text { Frictions }_{i, t-1} *(\text { Bankdebt } / \text { At })_{i, t-1} \\
& +(\text { 2nd order interactions }) \\
& +\gamma \text { Controls }_{i, t-1}+\lambda \text { Surprise }_{t} * \text { Controls }_{i, t-1}+\varepsilon_{i, t}
\end{aligned}
$$

and our coefficient of interest is $\beta_{4}$, which we predict is negative.

The bank lending channel also predicts that the sensitivity of bank-dependent firms to monetary policy changes should be stronger if a firm's lender is financially weak. Denoting BankHealth $h_{i, t-1}$ as the average financial health of the banks from which firm $i$ is borrowing,

\footnotetext{
${ }^{22}$ The evidence from earlier literature supports this part of the mechanism by showing that some borrowers are affected by their banks' financial health. See, for example, Paravisini (2008), Khwaja and Mian (2008), Chava and Purnanandam (2011), and Jimenez, Ongena, Peydró and Saurina (2012).
} 
this mechanism would predict that

$$
\frac{\partial^{3} \text { Ret }_{i, t}}{\partial \text { Surprise }_{t} \partial\left({\text { BankDebt } / A t)_{i, t-1} \partial \text { BankHealth }_{i, t-1}}_{\text {Bank }}\right.}>0 .
$$

We test this prediction using the following regression specification:

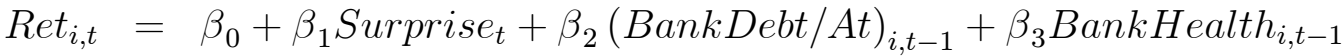

$$
\begin{aligned}
& +\beta_{4} \text { Surprise }_{t} *\left({\text { BankDebt } / A t)_{i, t-1}}_{*} \text { BankHealth }_{i, t-1}\right. \\
& +(\text { 2nd order interactions) } \\
& +\gamma \text { Controls }_{i, t-1}+\lambda \text { Surprise }_{t} * \text { Controls }_{i, t-1}+\varepsilon_{i, t}
\end{aligned}
$$

Our choice of proxies for bank financial health draws on the existing literature. Previous work has shown that monetary policy generates a stronger loan supply contraction by small banks (Kashyap and Stein [1995], and Kashyap and Stein [2000]) and by banks with lower capital ratios (Kishan and Opiela [2000], and Jimenez, Ongena, Peydró and Saurina [2012]). Accordingly, we take bank size and capital ratios as proxies for bank health. In specification (4) the coefficient of interest is $\beta_{4}$, which we predict to be positive.

For both specifications (3) and (4), we run a series of different regressions including fixedeffects at the firm, industry and year level, and clustering of errors at the firm, industry and date level. Among the controls we include leverage, firm size, profitability, and the marketto-book ratio, all entering the regression independently as well as interacted with surprise.

\subsection{Empirical Results}

We start by providing evidence on whether bank-dependent firms that are financially constrained are relatively more reactive to changes in monetary policy than bank-dependent

firms that are not financially constrained. The results are displayed in Table $\mathrm{V}$ and are 
consistent with the predictions of the bank lending channel. In particular, we find that bank dependence is not associated with significantly different stock price responses for rated firms or for firms in the top quartile of age. However, for the subsample of unrated firms, a two standard deviation (0.21) increase in bank dependence causes the stock price to decrease 1.54 $(=7.321 \times 0.21)$ percentage points more in response to a 1 percentage point increase in policy surprise. Similarly, a 1 percentage point increase in policy surprise leads to a stock price decrease which is $2.60(=12.371 \times 0.21)$ percentage points higher for firms in the bottom quartile of age. A similar, but statistically insignificant, result holds for small firms relative to large ones. ${ }^{23}$

\section{[TABLE V ABOUT HERE]}

In Table VI, we test whether the reaction of the stock price of bank-dependent firms to changes in monetary policy is affected by the financial health of their lenders. In Panel A, we proxy for a bank's financial health using its size. Consistent with the predictions of the bank lending channel, we find that bank-dependent firms that borrow from larger banks are less responsive to monetary policy when compared to bank-dependent firms that borrow from smaller banks. For the set of firms that borrow from banks in the bottom quartile of size distribution, a two standard deviation (0.22) increase in bank dependence causes the stock price to decrease $1.76(=7.812 \times 0.22)$ percentage points more in response to a 1 percentage point increase in policy surprise. ${ }^{24}$ For the set of firms borrowing from banks in the top quartile of size distribution, the same increase in bank dependence causes the stock price to increase by $1.12(=(12.790-7.812) \times 0.22)$ percentage points, following a 1 percentage

\footnotetext{
${ }^{23}$ There are variations in the sample size across the columns of Table V. In columns 3-6 we compare the first and fourth quartiles of each financial constraint measure, and this is why the number of observations is lower than in columns 1 and 2. In columns 3 and 4, the number of observations is even lower because the age variable is missing in Compustat for a large number of firms.

${ }^{24}$ Note that the standard deviation of bank dependence in the sample with bank health measures is slightly larger than the one obtained in the entire sample.
} 
point increase in policy surprise.

Panel B displays the results of the same regressions when we use bank capital ratios as the proxy for bank financial health. These results are also in line with the predictions of the bank lending channel, but statistically weaker. While an increase in bank dependence results in a stronger reaction to monetary policy shocks for firms borrowing from banks with a capital ratio in the bottom quartile, an increase in bank dependence results in a weaker reaction for those firms borrowing from banks with a capital ratio in the top quartile. ${ }^{25}$

\section{[TABLE VI ABOUT HERE]}

As a deeper analysis of our results, we also study whether bank-dependent firms that are less able to substitute alternative sources of debt financing for bank debt are relatively more affected by the health of their lenders. In particular, we run the same regressions in Table VII after sorting firms into two groups, depending on whether they have credit ratings and whether they are young or old. In Panel A, we observe that bank health, proxied by bank size, only affects bank-dependent firms' responsiveness to monetary policy if these firms are either unrated or young. Rated and old firms do not display such an effect. In fact, these firms seem to be more responsive to monetary policy shocks if they borrow from large banks, when compared to firms not dependent on banks, though the difference is statistically insignificant . In Panel B, in which bank health is proxied by the bank capital ratio, we observe similar results when comparing across rated and unrated firms, although the results are statistically insignificant. The same pattern does not appear, however, when we sort firms according to age, in part possibly due to the limited availability of data about firm age which causes large

\footnotetext{
${ }^{25}$ There is also evidence that less liquid banks react more to monetary policy shocks, most notably in Kashyap and Stein (2000) and Jimenez, Ongena, Peydró and Saurina (2012), although in the latter they find that the effect is weak. In unreported tests, we do not find the above effect of liquidity in our sample. This may be due to the decreased importance of liquidity reserve requirements for banks in developed economies in favor of capital requirements. The sample period used in Kashyap and Stein (2000) is 1976-1993, a period during which reserve requirements still played a role, particularly in the early part of the sample.
} 
loss in sample size.

\section{[TABLE VII ABOUT HERE]}

\subsection{Robustness}

The estimates of our coefficients of interest could suffer from endogeneity biases, mainly because of the omitted variables bias due to endogenous matching of banks to firms. In particular, bank financial health might influence the matching of firms to banks along the dimension of sensitivity to monetary policy. It could be that large and well capitalized banks specialize in riskier borrowers as they are more capable of coping with such risks. Or, in an opposite fashion, it could be that certain banks adopt conservative risk management practices that include high capitalization and the choice of safe borrowers. Either way, this endogenous matching would directly bias the coefficient estimate on the double interaction term Surprise $_{t} *$ BankHealth $h_{i, t-1}$.

More importantly, to the extent that the size of the bias depends on the degree of bank dependence of firms, the coefficient estimate on the triple interaction term Surprise $_{t} *$ $(\text { Bankdebt/At })_{i, t-1} *$ BankHealth $_{i, t-1}$, which is our coefficient of interest, could also be biased. One plausible and problematic story that could explain our results both for the double and triple interaction terms could go as follows; large and well capitalized banks choose riskier borrowers on average (negative and significant coefficient on Surprise $_{t} *$ BankHealth $_{i, t-1}$ ),

but when facing borrowers that demand large loans or are expected to draw down heavily on credit lines, they become relatively more conservative (positive and significant coefficient on Surprise $_{t} *\left(\right.$ Bankdebt/At $_{i, t-1} *$ BankHealth $\left._{i, t-1}\right)$. Even in the absence of this, the endogeneity of the double interaction term Surprise $_{t} *$ BankHealth $_{i, t-1}$ could render other coefficient estimates inconsistent.

To deal with these endogeneity concerns, we first evaluate the existence of endogenous 
matching of banks to firms on the basis of observable firm characteristics, and we later provide an instrumental variable estimation analysis.

\subsubsection{Endogenous Bank-Firm Matching Analysis}

In this subsection, we want to evaluate the impact of bank financial health on bank-firm matching, and how the association of bank financial health with risk-related firm characteristics changes with bank dependence. More precisely, we want to study if financially healthier banks (larger or better capitalized) are relatively more likely to be associated with less risky and less interest rate sensitive firms when these firms become more bank-dependent. Such pattern would introduce a bias that could account for the findings reported in Section 4.2.

Accordingly, we study how bank financial health, proxied by bank size and by the bank capital ratio, is associated with risk-related firm characteristics in Table VIII. In columns 1-3, we regress bank size on firm characteristics and include bank dependence interacted with all firm characteristics. We do not observe that larger banks are relatively more likely to become associated with less risky firms when these firms become more bank-dependent. If anything, in column 1 we observe that when firms increase their ratio of bank debt to total assets, larger banks are more closely associated with firms with higher cash flow volatility. Thus, in our findings there is no evidence supporting a type of endogenous matching of banks to firms that might introduce a problematic bias in our estimates in Tables VI and VII. The case is not as clear when we study the capital ratio as a measure of bank health in the regressions in columns 4-6. We find significant evidence that better capitalized banks are more likely to be matched to more interest rate sensitive firms as they become more bank-dependent, although the results reverse when we measure risk using CAPM beta.

[TABLE VIII ABOUT HERE] 


\subsubsection{Instrumental Variables Estimation}

As described above, we suspect that there are two variables which may suffer from an endogeneity bias due to a problem of omitted variables, a double and a triple interaction term. Our instrumental variables strategy is based on the idea that if we find a valid instrument for bank health, then the double and triple interaction terms using such an instrument are valid instruments for the potentially endogenous double and triple interaction terms included in the regression. We proceed below to describe the IV analysis for bank size and tier 1 capital ratios separately.

Bank Size IV Estimation We follow Berger et al. (2005) by introducing the log median size of banks in the Metropolitan Statistical Area (MSA) or rural county where a firm is located $(\operatorname{lnMSAp50)}$ ) as an instrument for the size of the bank(s) lending to a firm. The rationale for this measure is that a firm is more likely to form lending relationships with banks located closer to it (relevance condition), but that the median size of banks in a region does not directly affect daily stock returns of firms (exclusion restriction). This reasoning for the relevance and exclusion conditions of this instrument choice is assumed to extend to the double and triple interaction terms. More formally, to check for concerns about potential weakness of our instruments, we calculate the first-stage Cragg-Donald F-statistics for the first-stage regressions for the double and triple interaction terms, which are always above 100 in both, and we also calculate the t-statistics for the excluded instruments in the respective first-stage regressions, both of which have associated p-values always lower than 0.001 .

Given that OLS is preferred to instrumental variable regressions if the endogeneity problem is absent, we perform Durbin-Wu-Hausman tests for endogeneity and find that we cannot reject the null of exogeneity of the potentially endogenous double and triple interaction terms. In column 1 of Table IX, we report the results of the IV estimation for bank size and find that the coefficient on the triple interaction term is positive and highly significant, 
suggesting that there might be a strong negative bias in the OLS regression estimates for the triple interaction term. ${ }^{26}$ These results provide robustness to the evidence in favor of the presence of a bank lending channel of monetary policy in which bank-dependent firms that borrow from financially sound banks are less responsive to monetary policy than those borrowing from less healthy banks.

\section{[TABLE IX ABOUT HERE]}

Bank Capital Ratio IV Estimation We follow Ashcraft (2008) and Berger and Bouwman (2013) and introduce the corporate income tax rate in the state in which a firm is located $(\operatorname{tax})$ as an instrument for the capital ratio of the bank(s) lending to a firm. The rationale for this measure is that a firm is more likely to form lending relationships with banks located closer to it, and that because interest on debt is tax-deductible, but dividends are not, banks located in states with higher income tax rates are more likely to have lower capital ratios (relevance condition). On the other hand, a corporate income tax rate in a state is unlikely to directly affect the stock returns of firms in that state (exclusion restriction). This reasoning for the relevance and exclusion conditions of this instrument choice is assumed also to extend to the double and triple interaction terms. More formally, to check for concerns about potential weakness of our instruments, we calculate the first-stage CraggDonald F-statistics for the first-stage regressions for the double and triple interaction terms, which are 4.9 and 13.9, respectively, and we also calculate the t-statistics for the excluded instruments in the respective first-stage regressions, both of which have associated p-values always lower than 0.001. We perform Durbin-Wu-Hausman tests for endogeneity and find

\footnotetext{
${ }^{26}$ The large difference in the size of the estimated coefficients could also be due to other reasons. It could be that the OLS estimates are biased towards zero because of measurement error, and that the IV estimates suffer less from this problem. It could also be that there are heterogeneous effects in our main variable of interest, whose average changes substantially because of the use of an instrument. The impact of heterogeneous effects could also be different in the IV regressions because of the loss in sample size due to limited data availability for the instrument.
} 
that we cannot reject the null of exogeneity of the potentially endogenous double and triple interaction terms.

In column 2 of Table IX, we report the results of the IV estimation and find that the coefficient on the triple interaction term is positive and highly significant, in line with the OLS estimates, although the size of the coefficient estimate is much larger, as in the case of the bank size IV estimates. ${ }^{27}$ These results lend further support to the role of bank health in influencing the transmission of monetary policy to firms.

\section{Why is Bank Debt Special? (II) The Interest Rate Pass-Through Channel}

\subsection{Motivation of Empirical Predictions and Empirical Strategy}

An important empirical regularity is the widespread use of floating-rate agreements in bank loans and the prevalence of fixed-rate agreements in nonbank liabilities. Floating interest rates, also known as variable or adjustable rates, are typically calculated as a spread over a reference rate, such as LIBOR or the prime rate. In our sample (see Figure 1), $72 \%$ of debt is floating-rate for those firms whose entire stock of debt consists of bank debt. For those firms whose debt is entirely from nonbank sources, however, only around $10 \%$ of debt is floating-rate. In a sample of syndicated bank loans for the same period of our analysis, practically all of the loans are floating-rate. Using data for U.S. firms in the chemical industry between 1994 and 1999, Faulkender (2005) finds that 89.9\% of bank loans are issued with a floating-rate, compared to only $7 \%$ of bonds being floating-rate.

\footnotetext{
${ }^{27}$ The reasons driving the large size in the IV estimate are probably similar to the ones we discussed for the case of bank size. It is worth noting that the explanation for the difference in size based on a larger problem of measurement error in the OLS estimates is supported by the observation that the increase in size in the coefficients is larger in the case in which we instrument for capital ratios, which is more likely to be biased by measurement error given the relatively large accounting management possibilities bank managers enjoy, which impacts this variable's precision.
} 
The floating-rate nature of most bank debt suggests that monetary policy actions, to the extent that they induce changes in the reference rates used in the floating-rate agreements, should be reflected mechanically into the cost of existing bank loans for firms. This means that bank debt might be special for the transmission of monetary policy because variations in policy rates are more likely to result in a variation in the firm's interest expense and, as a result, in its profits. We call this channel the interest rate pass-through channel. In the absence of financing frictions, the impact on the firm's value would be the present value of the variation in the interest expense. In the presence of financing frictions, the impact could be amplified through the effect of variations in the interest expense on the firm's liquidity position and net worth and, ultimately, on its ability to finance profitable investment projects.

Our empirical strategy provides evidence for the pass-through channel by exploiting the variation across bank-dependent firms in their usage of floating-to-fixed interest rate hedging. Table I shows that this type of hedging is very common. Across the entire sample $29.90 \%$ of firms engage in floating-to-fixed hedging activity. This percentage increases significantly to $44.23 \%$ for the subsample of bank debt users, and is much lower (15.64\%) for nonbank debt users. Faulkender (2005) finds that $19.1 \%$ of the bank loans in his sample are swapped from floating-rate to fixed-rate. The prediction of the pass-through channel is that bankdependent firms that have hedged against interest rate risk should be, all else equal, less responsive to monetary policy shocks.

The firm's decision whether to hedge or not is clearly endogenous, however, and our choice of controls addresses possible biases arising from this endogeneity. Several reasons have been put forward for the widespread use of hedging instruments by firms, and most have to do with the presence of financing constraints. If firms face costs of raising external finance, they may find it optimal to hedge against low cash flow realizations to avoid having to forgo positive net-present-value (NPV) projects (Froot, Scharfstein and Stein [1993]) or to avoid non-linear 
costs of financial distress (Stulz [1984]) ${ }^{28}$ These theories predict that hedging activities are positively related to the severity of financing constraints. The empirical evidence, however, does not provide support for this prediction, and has documented that firms which are more likely to face financial constraints, such as small firms, are less likely to manage risk (Stulz [1996]). ${ }^{29}$ Motivated by these findings, Rampini, Sufi, and Viswanathan (2012) introduce and test a theory that suggests there is a trade-off between hedging and financing, because both activities compete for the same collateral. In equilibrium, firms that are more financially constrained hedge less. The important role of financing constraints in firms' willingness and ability to hedge suggests that one should control for financial constraints, and how these constraints interact both with the ability to raise debt and to hedge. Accordingly, we control for several measures of financial constraints, both uninteracted and interacted with monetary policy surprises and bank dependence.

We test the prediction that bank-dependent firms that hedge against interest rate risk should be, all else equal, less responsive to monetary policy shocks by using the following empirical specification:

\footnotetext{
${ }^{28}$ Other motivations for the use of hedging have to do with corporate governance and managerial incentives (Chava and Purnanandam [2007]), and with market timing (Faulkender [2005]). More generally, the value creation of hedging has been examined by Nance, Smith and Smithson (1993), Mian (1996) and Graham and Rogers (2002).

${ }^{29}$ Column 6 of Table A3 shows that this is the case also in our sample. Larger, rated and more profitable firms are more likely to hedge than their smaller, unrated, or less profitable counterparts.
} 


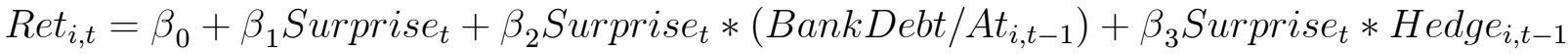

$$
\begin{aligned}
& +\beta_{4} \text { Surprise }_{t} *\left({\text { BankDebt } / A t)_{i, t-1} * H_{\text {Hedge }}, t-1}_{1}\right. \\
& +\beta_{5} \text { Surprise }_{t} *\left({\text { BankDebt } / \text { At })_{i, t-1} * \text { FinConstraint }_{i, t-1}}\right. \\
& +\beta_{6} \text { Surprise }_{t} * \text { FinConstraint }_{i, t-1}
\end{aligned}
$$

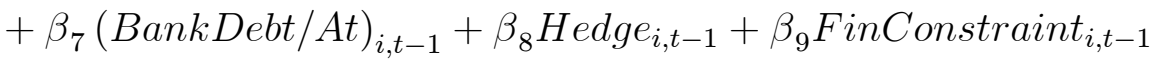

$$
\begin{aligned}
& +\beta_{10} H_{e d g e} e_{i, t-1} *(\text { BankDebt/At })_{i, t-1} \\
& +\beta_{11} \text { FinConstraint }_{i, t-1} *(\text { BankDebt } / A t)_{i, t-1} \\
& +\gamma \text { Controls }_{i, t-1}+\lambda \text { Surprise }_{t} * \text { Controls }_{i, t-1}+\varepsilon_{i, t}
\end{aligned}
$$

The coefficient of interest is $\beta_{4}$, and our prediction is that it is positive and significant, while we still expect to observe a negative and significant value for $\beta_{2}$. The simultaneous significance of these two coefficients with opposite signs would indicate that while being exposed to bank debt increases the sensitivity of a firm to monetary policy changes, by engaging in hedging activities firms can reduce the effects of such exposure. Quantitatively it is interesting to assess if the effect of hedging is strong enough to outweigh that of bank debt. If, conditional on hedging, there is no effect of bank debt on the relation between equity prices and interest rate changes, this would suggest that most of the higher sensitivity to interest rates associated with the use of bank debt is effectively operating via the floating-rate nature of this type of debt. ${ }^{30}$

\footnotetext{
${ }^{30}$ One important question is why many firms finance themselves with floating-rate debt and then subsequently hedge the interest rate risk associated with floating interest rates, instead of issuing fixed-rate debt. One possible argument is based on the well documented fact that financially constrained firms are more likely to rely on bank finance, which is mostly floating-rate, rather than bond finance, which is mostly fixed-rate (see columns 1-3 of Table A3 in the appendix, according to which smaller and unrated firms are more likely to borrow from banks, and also Houston and James (1996), Cantillo and Wright (2000), Hadlock and James (2002), and Denis and Mihov (2003)). One can then argue that insofar as some firms prefer fixed-rate debt but cannot access the bond market, we should expect these firms to swap their floating rate
} 


\subsection{Empirical Results}

The results of our tests are provided in Table $\mathrm{X}$ and are consistent with our predictions. In Panel A, we begin with a simplified version of the specification provided in (5), where we exclude the triple interaction terms and the financial constraints. In columns 1 and 2 , we examine the sample of hedgers, and in columns 3 and 4 the sample of non-hedgers. We find that a surprise increase of 1 percentage point in the federal funds rate causes the value of a firm with average bank debt (0.104 in column 1 and 0.038 in column 3) to drop by $5.88 \%$ and $4.85 \%$, respectively. In column 1 , the non-significance of the interaction term for Surprise* $($ BankDebt/At) indicates that the relation between bank debt and the sensitivity to federal funds rate changes disappears when a firm swaps its interest rates from floating to fixed. On the contrary, for non-hedgers the interaction term of bank debt with policy surprise is negative and significant, suggesting that within this subsample firms that rely more on bank finance are more sensitive to interest rate changes. More precisely, for the set of non-hedgers the interaction term shows that the effect of a two standard deviation increase in bank dependence (0.264), on the response to a 1 percentage point increase in surprise is a further drop in the value of equity of $1.56 \% .^{31}$

Panel B contains a set of estimates for the full model provided in equation (5) us-

for a fixed rate. Yet another question is why bank credit is mostly floating-rate, while non-bank debt is mostly fixed-rate. Banks might have a preference for floating-rate loans due to regulatory reasons associated with required capital ratios. Relatedly, given that a large part of bank liabilities are short term (deposits and wholesale financing for example), and hence are particularly sensitive to short-term interest rates (Landier, Sraer and Thesmar (2013)), banks achieve a better hedging of interest rate risk on their liabilities by issuing floating-rate loans on their asset side.

${ }^{31}$ In columns 2 and 4 we replace bank dependence with FloatingRateDebt/At, which is the ratio of floating rate debt over total assets. In line with our previous results, we also find that the impact of floating rate debt usage on the responsiveness to monetary policy is greater for firms that do not hedge interest rate risk, although the difference is not statistically significant. Given that the floating-rate nature of bank debt is the driver of the pass-through channel, we would have expected that a direct measure of floating rate debt usage, irrespective of whether it is bank or non-bank debt, would have a significant impact on the sensitivity to monetary policy. Because most bank debt is floating rate, the additional information contained in our floating rate variable is the presence of floating rate bonds. The low statistical significance could then be due the possibility that floating rate non-bank debt is special in some way, for example because it captures very short-term instruments such as commercial paper, or because most floating rate bond users swap their floating rates for fixed rates, so that most bonds end up paying a fixed rate. 
ing different measures of financial constraints based on rating, size and age (Almeida, Campello, and Weisbach [2004], Hadlock and Pierce [2013]). The coefficient $\beta_{2}$ for Surprise* (BankDebt/At) is negative and significant, indicating that the equity prices of bank debt users are more sensitive to federal funds rate changes. At the same time, $\beta_{4}$, the coefficient for the triple interaction term Surprise $*(B a n k D e b t / A t) * H e d g i n g$, is positive and significant (in two out of three cases) after controlling for how financial constraints interact with the exposure to bank debt, which is consistent with our prediction that bank-dependent firms that hedge against interest rate risk should be, all else equal, less responsive to monetary policy shocks.

\section{[TABLE X ABOUT HERE]}

In Table XI, we examine how monetary policy affects the cost of debt of firms, and how this effect varies across firms depending on their bank dependence and their hedging activity. We compute the average cost of debt as the ratio of interest expenses (Compustat item 15) over total debt (Compustat item 9 plus item 34) at the end of the previous year. The prediction that we want to test is that the cost of debt should be more sensitive to changes in the federal funds rate for firms that are financed with bank debt, but less so if they hedge their interest rate risk. For this purpose, we set up a regression specification which is analogous to that provided in equation (5) (excluding financial constraints), where policy surprise is replaced by the actual change in the federal funds rate and the dependent variable is the average cost of debt in the year following the one in which the monetary policy event takes place. Column 1 of Table XI shows that the average cost of debt is positively and significantly related to change. Columns 2 and 3 show that bank debt usage is weakly positively associated with the sensitivity of the cost of debt to change. Once we control for

hedging in column 4, the coefficient for bank debt users becomes positive and significant, 
suggesting that users of bank debt that do not hedge have a cost of debt which is significantly more sensitive to changes in the federal funds rate. At the same time, the triple interaction term of Change * $($ BankDebt/At $) *$ Hedging is negative and significant, indicating that hedgers have a cost of debt which is relatively less sensitive. These findings confirm and complement the results provided in Table $\mathrm{X}$ by providing further evidence consistent with the proposed mechanism of the interest rate pass-through channel.

\section{[TABLE XI ABOUT HERE]}

\section{Conclusion}

Our analysis concludes that bank lending to firms plays an important role in the transmission of monetary policy. We show that stock prices of bank-dependent firms are significantly more responsive to monetary policy shocks. We also find evidence that supports two channels consistent with this pattern. The first channel is the traditional bank lending channel, which argues that financial constraints of banks amplify the impact of monetary policy because monetary policy affects the strength of banks' balance sheets. The second and new channel is the interest rate pass-through channel, based on the direct pass-through of policy rates to lending rates. Our results also suggest that there is significant heterogeneity across bank-dependent firms in their reaction to monetary policy shocks.

Our paper is the first to analyze the impact of monetary policy on firms using bank debt usage as a measure of bank dependence. This precise and quantifiable measure of bank dependence allows us to make quantitative assessments about the transmission mechanisms we analyze. Moreover, we combine this measure with the financial health of firms' lenders and with firms' hedging activities to create a rich database that allows us to explore the different transmission mechanisms of monetary policy that operate through bank lending in 
detail.

We contribute to the macroeconomics literature by providing new evidence on the mechanisms through which monetary policy has implications for the real economy. We also contribute to the corporate finance literature by increasing our understanding of the determinants and implications of different capital structure choices, and of the consequences of risk management decisions. Moreover, by showing that bank financial health can have an important influence on its borrowers' sensitivity to monetary policy, we contribute to the understanding of the banking literature about banks' sensitivity to monetary policy. Finally, our results are relevant to researchers and investors interested in asset pricing, and in particular on how monetary policy shocks affect stock prices.

While we address several questions simultaneously there is still significant room for additional research which extends our approach. A direct extension can focus on the period of unconventional monetary policy that started in 2008 and its effect on the bank lending and the interest rate pass-through channels. We believe this to be a very important question, amongst other reasons because it would address one of the main criticisms of the current monetary policy which is that banks have been hoarding cash in their reserve accounts rather than originating new loans. We leave this extension for future research, pending a reliable measure of monetary policy surprises in the unconventional policy period. 


\section{APPENDIX}

[TABLE A1 ABOUT HERE]

[TABLE A2 ABOUT HERE]

[TABLE A3 ABOUT HERE] 


\section{References}

[1] Almeida, Heitor, Murillo Campello, and Michael S. Weisbach, "The Cash Flow Sensitivity of Cash," Journal of Finance, 59 (2004), 1777-1804.

[2] Amihud, Y. (2002): Illiquidity and stock returns: cross-section and time-series effects, Journal of Financial Markets 5, pp. 31-56

[3] Angeloni, Ignazio, Anil K. Kashyap, and Benoit Mojon, ed., "Monetary Policy Transmission in the Euro Area," 2003, Cambridge University Press.

[4] Ashcraft, Adam, "New Evidence on the Lending Channel," Journal of Money, Credit, and Banking, 32 (2006), 751-776.

[5] Ashcraft, Adam B., "Does the Market Discipline Banks? New Evidence from Regulatory Capital Mix," Journal of Financial Intermediation, 17 (2008), 543-561.

[6] Berger, Allen N., and Christa HS, Bouwman, "How Does Capital Affect Bank Performance during Financial Crises?," Journal of Financial Economics, 109 (2013), 146-176.

[7] Berger, Allen N., Nathan H. Miller, Mitchell A. Peterson, Raghuram G. Rajan, Jeremy C. Stein, "Does Function Follow Organizational Form? Evidence from the Lending Practices of Large and Small Banks," Journal of Financial Economics, 76 (2005), 237269.

[8] Bernanke, Ben S., and Alan S. Blinder, "Credit, Money, and Aggregate Demand," American Economic Review, 78 (1988), 435-439.

[9] - "The Federal Funds Rate and the Channels of Monetary Transmission," American Economic Review, 82 (1992), 901-921.

[10] Bernanke, Ben S., and Mark Gertler, "Inside the Black Box: The Credit Channel of Monetary Policy Transmission," Journal of Economic Perspectives, 9 (1995), 27-48.

[11] Bernanke, Ben S., and Kenneth N. Kuttner, "What Explains the Stock Market's Reaction to Federal Reserve Policy?," Journal of Finance, 60 (2005), 1221-1257.

[12] Boivin, Jean, and Marc P. Giannoni, 2006. "Has Monetary Policy Become More Effective?," Review of Economics and Statistics, 88 (2006), 445-462.

[13] Bolton, Patrick, and Xavier Freixas, "Corporate Finance and the Monetary Transmission Mechanism," Review of Financial Studies, 19 (2006), 829-870.

[14] Cantillo, Miguel, and Julian Wright, "How Do Firms Choose Their Lenders? An Empirical Investigation," Review of Financial Studies, 13 (2000), 155-189.

[15] Carvalho, Daniel, Miguel Ferreira, and Pedro Matos, "Lending Relationships and the Effect of Bank Distress: Evidence from the 2007-2008 Financial Crisis," mimeo, 2011. 
[16] Chava, Sudheer, and Amiyatosh Purnanandam. "Determinants of the floating-to-fixed rate debt structure of firms." Journal of Financial Economics 85.3 (2007): 755-786.

[17] — , "The Effect of Banking Crisis on Bank-Dependent Borrowers," Journal of Financial Economics, 99 (2011), 116-135.

[18] Chernenko, Sergey, and Michael Faulkender, "The Two Sides of Derivatives Usage: Hedging and Speculating with Interest Rate Swaps," Journal of Financial and Quantitative Analysis, 46 (2011), 1727-1754

[19] Chodorow-Reich, Gabriel, "The Employment Effects of Credit Market Disruptions: Firm-level Evidence from the 2008-09 Financial Crisis," mimeo, 2013.

[20] Colla, Paolo, Filippo Ippolito, and Kai Li, "Debt Specialization," Journal of Finance, forthcoming, 2013.

[21] Daniel, Kent D., and Sheridan Titman, "Evidence on the Characteristics of Cross Sectional Variation in Stock Returns, Journal of Finance 52 (1997), 1-33.

[22] Denis, David J., and Vassil T. Mihov, "The Choice among Bank Debt, Non-Bank Private Debt, and Public Debt: Evidence from New Corporate Borrowings," Journal of Financial Economics, 70(2003), 3-28.

[23] Ehrmann, Michael, and Marcel Fratzscher, "Taking Stock: Monetary Policy Transmission to Equity Markets," Journal of Money, Credit, and Banking, 36 (2004): 719-737.

[24] Evans, Charles L., "Real-Time Taylor Rules and the Federal Funds Futures Market," Economic Perspectives, 22(1998), 44-55.

[25] Fama, Eugene F., and Kenneth R. French, "The Cross-Section of Expected Stock Returns." Journal of Finance, 47 (1992), 427-465.

[26] — "Size and Book-to-Market Factors in Earnings and Returns," Journal of Finance, 50 (1995), 131-155.

[27] Faulkender, Michael, "Hedging or Market Timing? Selecting the Interest Rate Exposure of Corporate Debt," Journal of Finance, 60 (2005), 931-962.

[28] Ferson, Wayne E., and Campbell R. Harvey, "Conditioning Variables and the Cross Section of Stock Returns," Journal of Finance, 54 (1999), 1325-1360.

[29] Froot, Kenneth A., David S. Scharfstein, and Jeremy C. Stein "Risk Management: Coordinating Corporate Investments and Financing Policies." Journal of Finance, 5 (1993), 1629-1658.

[30] Gertler, Mark, and Simon Gilchrist, "Monetary Policy, Business Cycles, and the Behavior of Small Manufacturing Firms," Quarterly Journal of Economics, 109 (1994): 309-340. 
[31] Giannetti, Mariassunta, and Andrei Simonov, "On the Real Effects of Bank Bailouts: Micro-Evidence from Japan," CEPR Discussion Papers 7441, C.E.P.R., 2009.

[32] Graham, John R., and Daniel A. Rogers, "Do Firms Hedge in Response to Tax Incentives?," Journal of Finance, 57 (2002), 815-839.

[33] Gurkaynak, Refet S., Brian Sack, and Eric T. Swanson, "Do Actions Speak Louder than Words? The Response of Asset Prices to Monetary Policy Actions and Statements," International Journal of Central Banking, 1 (2005), 55-93.

[34] Hadlock, Charles J., and Christopher M. James, "Do Banks Provide Financial Slack?," Journal of Finance, 57 (2002), 1383-1419.

[35] Hadlock, Charles J., and Joshua R. Pierce, "New Evidence on Measuring Financial Constraints: Moving Beyond the KZ Index," Review of Financial Studies, 23 (2010), $1909-1940$.

[36] Houston, Joel, and Christopher James, "Bank Information Monopolies and the Mix of Private and Public Debt Claims," Journal of Finance, 51 (1996), 1863-1889.

[37] Jiménez, Gabriel, Steven Ongena, Jose-Luis Peydró, and Jesus Saurina, "Credit Supply and Monetary Policy: Identifying the Bank Balance-Sheet Channel with Loan Applications," American Economic Review, 102 (2012), 2301-2326.

[38] Kang, Jun-Koo, and Rene M. Stulz, "Do Banking Shocks Affect Firm Performance? An Analysis of the Japanese Experience", Journal of Business, 73 (2000), 1-23.

[39] Kashyap, Anil K. , and Jeremy C. Stein, "The Impact of Monetary Policy on Bank Balance Sheets," Carnegie-Rochester Conference Series on Public Policy, 42 (1995), 151-195.

[40] - "What Do a Million Observations on Banks Say About the Transmission of Monetary Policy?," American Economic Review, 90 (2000), 407-428.

[41] Khwaja, Asim, and Atif Mian, "Tracing the Impact of Bank Liquidity Shocks: Evidence from an Emerging Market," American Economic Review, 98 (2008), 1413-1442.

[42] Kishan, Ruby P., and Timothy P. Opiela, "Bank Size, Bank Capital, and the Bank Lending Channel," Journal of Money, Credit and Banking, 32 (2000), 121-141.

[43] Kuttner, Kenneth N., "Monetary Policy Surprises and Interest Rates: Evidence from the Fed Funds Futures Market," Journal of Monetary Economics, 47 (2001), 523-544.

[44] Landier, Augustin, David A. Sraer, and David Thesmar, "Banks' Exposure to Interest Rate Risk and the Transmission of Monetary Policy," NBER Working Paper No. 18857, 2013. 
[45] Mian, Shehzad L., "Evidence on Corporate Hedging Policy," Journal of Financial and Quantitative Analysis, 31 (1996), 419-439.

[46] Nance, Deana R., Clifford W. Smith, and Charles W. Smithson, "On the Determinants of Corporate Hedging," Journal of Finance 48 (1993), 267-284.

[47] Nizalova, Olena, and Irina Murtazashvili, "Exogenous Treatment and Endogenous Factors: Vanishing of Omitted Variable Bias on the Interaction Term," IZA Discussion Paper No. 6282, 2012.

[48] Ongena, Steven, and David C. Smith, and Dag Michalsen, 2003. "Firms and Their Distressed Banks: Lessons from the Norwegian Banking Crisis," Journal of Financial Economics, 67 (2003), 81-112.

[49] Paravisini, Daniel, "Local Bank Financial Constraints and Firm Access to External Finance," Journal of Finance, 63 (2008), 2161-2193.

[50] Peek, Joe, and Eric S. Rosengren, "Collateral Damage: Effects of the Japanese Bank Crisis on Real Activity in the United States," American Economic Review, 90 (2000): $30-45$.

[51] Piazzesi, Monika, and Eric T. Swanson, "Futures Prices as Risk-Adjusted Forecasts of Monetary Policy," Journal of Monetary Economics, 55 (2008), 677-691.

[52] Rampini, Adriano A., Amir Sufi, and S. Viswanathan, "Dynamic Risk Management," Journal of Financial Economics, forthcoming, 2013.

[53] Rigobon, Roberto, and Brian Sack, "The Effects of War Risk on US Financial Markets," Journal of Banking and Finance, 29 (2005), 1769-1789.

[54] Smith, Clifford W., and René M. Stulz, "The Determinants of Firms' Hedging Policies," Journal of Financial and Quantitative Analysis, 28 (1985), 391-405.

[55] Stein, Jeremy, "An Adverse-Selection Model of Bank Asset and Liability Management with Implications for the Transmission of Monetary Policy," RAND Journal of Economics, 29 (1998), 466-486.

[56] Stulz, René M., "Optimal Hedging Policies," Journal of Financial and Quantitative Analysis, 19 (1984), 127-140.

[57] —, "Rethinking Risk Management," Journal of Applied Corporate Finance, 9 (1996), 8-25.

[58] Sufi, Amir, "Bank Lines of Credit in Corporate Finance: An Empirical Analysis," Review of Financial Studies, 22 (2009), 1057-1088. 
[59] Van den Heuvel, Skander J., "Does Bank Capital Matter for Monetary Transmission?," Economic Policy Review, Federal Reserve Bank of New York, Issue May (2002), 259265. 
Table I

Descriptive Statistics

\begin{tabular}{lccccc}
\hline & $(1)$ & $(2)$ & $(3)$ & $(4)$ & $(5)$ \\
\cline { 2 - 5 } & Entire & Firms with & Firms without & Leveraged & Unleveraged \\
& Sample & Bank Debt & Bank Debt & W/out Bank & Mean \\
\cline { 2 - 5 } Term Loans/At & Mean & Mean & Mean & $0.00 \%$ & $0.00 \%$ \\
Drawn Credit Lines/At & $2.69 \%$ & $6.73 \%$ & $0.00 \%$ & $0.00 \%$ & $0.00 \%$ \\
Bank Debt /At & $2.30 \%$ & $5.73 \%$ & $0.00 \%$ & $0.00 \%$ & $0.00 \%$ \\
Bank Debt / Total Debt & $5.11 \%$ & $12.77 \%$ & $0.00 \%$ & $0.00 \%$ & $0.00 \%$ \\
Undrawn Credit Line/At & $36.34 \%$ & $57.01 \%$ & $0.00 \%$ & $6.92 \%$ & $5.42 \%$ \\
(Bank Debt + Und CL/)At & $9.22 \%$ & $11.95 \%$ & $6.32 \%$ & $6.92 \%$ & $5.42 \%$ \\
Profitability & $15.81 \%$ & $24.72 \%$ & $6.32 \%$ & $3.07 \%$ & $3.04 \%$ \\
Size (Total Assets) & $4.05 \%$ & $5.54 \%$ & $3.05 \%$ & 3984.4 & 453.6 \\
Book Leverage & 2626.9 & 3891.7 & 1782.7 & $26.53 \%$ & $0.00 \%$ \\
Interest Rate Sensitivity & $20.76 \%$ & $36.97 \%$ & $9.93 \%$ & $-11.66 \%$ & $-8.96 \%$ \\
Hedging Dummy & $-11.35 \%$ & $-13.30 \%$ & $-10.01 \%$ & $24.55 \%$ & $0.00 \%$ \\
Rated Dummy & $29.90 \%$ & $44.23 \%$ & $15.64 \%$ & $30.93 \%$ & $1.39 \%$ \\
Floating-Rate Debt/At & $22.02 \%$ & $36.57 \%$ & $12.42 \%$ & $2.04 \%$ & $0.00 \%$ \\
Float-Rate Debt / Tot.Debt & $6.19 \%$ & $10.80 \%$ & $1.29 \%$ & $11.43 \%$ & $0.00 \%$ \\
Short-Term Debt /At & $32.71 \%$ & $44.82 \%$ & $11.39 \%$ & $2.25 \%$ & $0.00 \%$ \\
Observations & $2.17 \%$ & $4.14 \%$ & $0.87 \%$ & & 4909 \\
\hline
\end{tabular}

This table provides summary statistics for the entire sample and for different subsamples. The entire sample consists of U.S. firms covered by Capital IQ, CRSP and Compustat from 2003 to 2008, excluding utilities (SIC codes 49004949) and financials (SIC codes 6000-6999). We remove firm-year observations with negative revenues, missing information on total assets, or a value of total assets under 10 million. We also discard penny stocks, defined as those with a price of less than $\$ 5$. After the above filters, the sample contains 21,745 firm-year observations comprising 4,408 unique firms. Complete variable definitions are given in the appendix. All variables are winsorized at the $1 \%$ level in both tails of the distribution, and total assets are expressed in terms of year-2000 dollars. 
Table II

Response of Equity Prices to Federal Funds Rate Changes: Comparison Across Samples

\begin{tabular}{|c|c|c|c|c|c|}
\hline & $\begin{array}{c}(1) \\
\text { Daily Value- } \\
\text { weighted Index } \\
\text { 1994-2008 } \\
\end{array}$ & $\begin{array}{c}(2) \\
\text { Daily Panel } \\
\text { All Firms } \\
\text { 1994-2008 } \\
\end{array}$ & $\begin{array}{c}(3) \\
\text { Daily Panel } \\
\text { All Firms } \\
\text { 1994-2002 } \\
\end{array}$ & $\begin{array}{c}(4) \\
\text { Daily Panel } \\
\text { All Firms } \\
\text { 2003-2008 } \\
\end{array}$ & $\begin{array}{c}(5) \\
\text { Daily Panel } \\
\text { Our Sample } \\
\text { 2003-2008 } \\
\end{array}$ \\
\hline Expected & $\begin{array}{l}0.421 \\
(1.00)\end{array}$ & $\begin{array}{c}0.209 * * * \\
(8.40)\end{array}$ & $\begin{array}{c}0.193 * * * \\
(5.73)\end{array}$ & $\begin{array}{c}0.133 * * * \\
(3.90)\end{array}$ & $\begin{array}{c}0.234 * * * \\
(5.49)\end{array}$ \\
\hline Surprise & $\begin{array}{c}-3.359 * * \\
(-2.05)\end{array}$ & $\begin{array}{c}-2.704^{* * *} \\
(-32.46)\end{array}$ & $\begin{array}{c}-2.424 * * * \\
(-25.67)\end{array}$ & $\begin{array}{c}-4.665^{* * *} \\
(-25.64)\end{array}$ & $\begin{array}{c}-4.401 * * * \\
(-21.22)\end{array}$ \\
\hline \# Observations & 115 & 536,357 & 363,290 & 173,067 & 99,047 \\
\hline
\end{tabular}

The table reports the results from regressions of 1-day equity returns on the surprise and expected components of the change in the federal funds rate, all expressed in percentage terms. Outliers are excluded. As in Bernanke and Kuttner (2005), for the period 1994-2002 outliers include October 15, 1998, January 3, 2001, March 20, 2001, April 18, 2001, and September 17, 2001. For the period 2003-2008, outlier dates are January 22, 2008, and March 18, 2008 based on based on a Cook's D statistic greater than 0.1. Column 1 contains returns for a value-weighted equity index. Columns 2-5 report returns for individual firm-date observations over different sample periods. Column 5 includes only observations for which data on bank debt is available. The firm level regressions contain random effects. Parentheses contain t-statistics. The asterisks denote $* * *$ for $\mathrm{p}<0.01$, ** for $\mathrm{p}<0.05$, * for $\mathrm{p}<0.1$. 
Table III

Is Bank Debt Special for the Transmission of Monetary Policy?

\begin{tabular}{|c|c|c|c|c|c|c|c|c|}
\hline & $\begin{array}{c}(1) \\
\text { No } \\
\text { Controls }\end{array}$ & $\begin{array}{c}(2) \\
\text { With } \\
\text { Controls }\end{array}$ & $\begin{array}{c}(3) \\
\text { Controls and } \\
\text { Ind. FE }\end{array}$ & $\begin{array}{c}(4) \\
\text { Event-indust. } \\
\text { Clustering }\end{array}$ & $\begin{array}{c}(5) \\
\text { Including } \\
\text { Credit Lines }\end{array}$ & $\begin{array}{c}\text { (6) } \\
\text { Int. Rate } \\
\text { Sensitivity }\end{array}$ & $\begin{array}{c}(7) \\
\text { Firm Fixed } \\
\text { Effects }\end{array}$ & $\begin{array}{c}\text { (8) } \\
\text { Interacted Firm } \\
\text { Fixed Effects }\end{array}$ \\
\hline Surprise & $\begin{array}{c}-4.221^{* * *} \\
(-20.57)\end{array}$ & $\begin{array}{c}-7.949 * * * \\
(-32.95)\end{array}$ & $\begin{array}{c}-7.170 * * * \\
(-6.152)\end{array}$ & $\begin{array}{c}-7.170 \\
(-1.417)\end{array}$ & $\begin{array}{c}-7.301 \\
(-1.446)\end{array}$ & $\begin{array}{c}-7.730 \\
(-1.538)\end{array}$ & $\begin{array}{c}-7.950 * * * \\
(-6.464)\end{array}$ & \\
\hline Surprise*(BankDebt/At) & $\begin{array}{c}-4.955^{* * *} \\
(-2.608)\end{array}$ & $\begin{array}{c}-6.763 * * * \\
(-3.032)\end{array}$ & $\begin{array}{c}-6.962 * * * \\
(-3.007)\end{array}$ & $\begin{array}{c}-6.962 * * * \\
(-2.602)\end{array}$ & $\begin{array}{c}-6.843 * * * \\
(-3.349)\end{array}$ & $\begin{array}{c}-6.610^{* *} \\
(-2.280)\end{array}$ & $\begin{array}{c}-7.048 * * \\
(-2.172)\end{array}$ & $\begin{array}{c}-9.710^{* *} \\
(-2.035)\end{array}$ \\
\hline Surprise*LnAssets & & $\begin{array}{c}-0.956 * * * \\
(-7.093)\end{array}$ & $\begin{array}{c}-0.990 * * * \\
(-6.837)\end{array}$ & $\begin{array}{c}-0.990 * * * \\
(-5.249)\end{array}$ & $\begin{array}{c}-1.012 * * * \\
(-5.242)\end{array}$ & $\begin{array}{c}-0.992 * * * \\
(-5.346)\end{array}$ & $\begin{array}{c}-1.007 * * * \\
(-5.026)\end{array}$ & $\begin{array}{c}-4.947 * * \\
(-2.502)\end{array}$ \\
\hline Surprise*Book Leverage & & $\begin{array}{c}2.669 * * * \\
(2.865)\end{array}$ & $\begin{array}{c}3.001 * * * \\
(3.056)\end{array}$ & $\begin{array}{c}3.001 * * * \\
(2.803)\end{array}$ & $\begin{array}{c}3.091 * * * \\
(3.007)\end{array}$ & $\begin{array}{c}3.262 * * * \\
(3.220)\end{array}$ & $\begin{array}{c}2.883^{* *} \\
(2.321)\end{array}$ & $\begin{array}{c}9.561 * * * \\
(3.693)\end{array}$ \\
\hline Surprise*Profitability & & $\begin{array}{c}-9.818^{* * *} \\
(-6.462)\end{array}$ & $\begin{array}{c}-8.121 * * * \\
(-4.660)\end{array}$ & $\begin{array}{c}-8.121 * * \\
(-2.462)\end{array}$ & $\begin{array}{c}-7.606 * * \\
(-2.319)\end{array}$ & $\begin{array}{c}-8.961^{* *} \\
(-2.469)\end{array}$ & $\begin{array}{c}-9.121 * * \\
(-2.094)\end{array}$ & $\begin{array}{c}-16.55 * * \\
(-2.046)\end{array}$ \\
\hline Surprise*M/B & & $\begin{array}{c}0.172 \\
(1.111)\end{array}$ & $\begin{array}{l}-0.0326 \\
(-0.190)\end{array}$ & $\begin{array}{l}-0.0326 \\
(-0.105)\end{array}$ & $\begin{array}{l}-0.0563 \\
(-0.179)\end{array}$ & $\begin{array}{c}0.0219 \\
(0.0702)\end{array}$ & $\begin{array}{c}0.267 \\
(0.696)\end{array}$ & $\begin{array}{c}-0.390 \\
(-0.604)\end{array}$ \\
\hline Surprise*Int Rate Sensitivity & & & & & & $\begin{array}{c}-4.088^{* *} \\
(-2.307)\end{array}$ & & \\
\hline Surprise*Cash-Flow Volatility & & & & & & $\begin{array}{c}41.99 \\
(0.506)\end{array}$ & & \\
\hline Surprise*Beta & & & & & & $\begin{array}{l}0.737^{*} \\
(1.867)\end{array}$ & & \\
\hline Firm FE & NO & NO & NO & NO & NO & NO & YES & YES \\
\hline FF48 Industry FE & NO & NO & NO & YES & YES & YES & NO & NO \\
\hline Year FE & NO & YES & YES & YES & YES & YES & YES & YES \\
\hline Interacted FF48 Industry FE & NO & NO & NO & YES & YES & YES & NO & NO \\
\hline Cluster (Fed event*IndustryFF48) & $\mathrm{NO}$ & NO & YES & YES & YES & YES & YES & YES \\
\hline Observations & 99,047 & 98,629 & 95,846 & 95,846 & 95,690 & 95,846 & 98,629 & 98,629 \\
\hline
\end{tabular}

This table examines how the reaction of firm equity prices to changes in the federal funds rate varies with their level of bank dependence. The sample consists of U.S. firms covered by Capital IQ, CRSP and Compustat from 2003 to 2008, excluding utilities (SIC codes 4900-4949) and financials (SIC codes 6000-6999). We remove firm-year observations with negative revenues, missing information on total assets, or a value of total assets under 10 million. We also discard penny stocks, defined as those with a price of less than $\$ 5$. The sample comprises 43 monetary policy events from 2003 to 2008. Firm characteristics are demeaned and are lagged by one year and winsorized at the $1 \%$ level. The regression specification is as in equation (1). Unreported terms include a constant and non-interacted coefficients. In specification (5) undrawn credit lines are computed as part of bank debt, in addition to drawn credit lines and term loans. Standard errors are clustered at the date level in specifications (1)-(2) and two-way clustered at the date and industry levels in specifications (4)-(8). Industries are defined according to the Fama-French 48 sectors. Parentheses contain t-statistics. The asterisks denote $* * *$ for $\mathrm{p}<0.01$, ** for $\mathrm{p}<0.05$, $*$ for $\mathrm{p}<0.1$. 
Table IV

Short-Term Debt and the Response of Equity Prices to Federal Funds Rate Changes

$\begin{array}{lllll}1 & (2) & (3) & (4)\end{array}$

Surprise
Surprise*(ShortTermDebt/At)
Surprise*(BankDebt/At)
Surprise*(ShortTermDebt/At)*(BankDebt/At)

$\begin{array}{cccccc}-4.148 * * * & -7.459 & -4.221 * * * & -6.988 & -4.189 * * * & -6.993 \\ (-20.40) & (-1.490) & (-20.56) & (-1.388) & (-20.16) & (-1.388) \\ 6.281 & 6.362 & 7.508 * & 7.841 & 9.498 * * & 11.36 * * \\ (1.526) & (1.165) & (1.754) & (1.488) & (2.017) & (2.197) \\ & & -5.707 * * * & -7.362 * * * & -5.419 * * * & -6.622 * * \\ & & (-2.930) & (-2.733) & (-2.752) & (-2.401) \\ & & & & -27.329 & -41.41 \\ & & & & (-1.01) & (-1.215)\end{array}$

Firm Characteristics

\begin{tabular}{lccccc} 
NO & YES & NO & YES & NO & YES \\
NO & YES & NO & YES & NO & YES \\
NO & YES & NO & YES & NO & YES \\
NO & YES & NO & YES & NO & YES \\
NO & YES & NO & YES & NO & YES \\
01,094 & 96,028 & 99,023 & 95,846 & 99,023 & 95,846 \\
\hline
\end{tabular}

FF48 Industry FE

Year FE

Interacted FF48 Industry FE

Cluster (Fed event*IndustryFF48)

Observations

$101,094 \quad 96,028$

99,023 95,846

This table examines how the reaction of firm equity prices to changes in the target federal funds rate varies with their usage of short-term debt. Short-Term Debt/At is defined as debt in current liabilities (item 34) over book value of assets. Columns 2, 4 and 6 include (unreported) interacted and non-interacted ln(assets), profitability and the market-to-book ratio. All firm characteristics are lagged by one year, demeaned, and winsorized at $1 \%$. Parentheses contain t-statistics. The asterisks denote $* * *$ for $\mathrm{p}<0.01$, ** for $\mathrm{p}<0.05$, * for $\mathrm{p}<0.1$. 
Table V

Bank Debt Specialness and Firm Financing Constraints

\begin{tabular}{|c|c|c|c|c|c|c|}
\hline & (1) & (2) & (3) & (4) & (5) & (6) \\
\hline & & & & & & \\
\hline Surprise & $\begin{array}{c}-5.759 * * * \\
(-15.89)\end{array}$ & $\begin{array}{c}-4.437 * * * \\
(-3.993)\end{array}$ & $\begin{array}{c}-5.617 * * * \\
(-9.119)\end{array}$ & $\begin{array}{c}-5.428 * * * \\
(-3.009)\end{array}$ & $\begin{array}{c}-6.052 * * * \\
(-15.74)\end{array}$ & $\begin{array}{c}-7.054 * * * \\
(-3.850)\end{array}$ \\
\hline Surprise*(BankDebt/At) & $\begin{array}{c}1.304 \\
(0.428)\end{array}$ & $\begin{array}{c}-3.881 \\
(-0.697)\end{array}$ & $\begin{array}{c}-1.121 \\
(-0.191)\end{array}$ & $\begin{array}{c}-3.556 \\
(-0.429)\end{array}$ & $\begin{array}{c}3.385 \\
(0.897)\end{array}$ & $\begin{array}{c}-0.987 \\
(-0.176)\end{array}$ \\
\hline Surprise*Fin. Constraint Measure & $\begin{array}{c}2.250 * * * \\
(5.088)\end{array}$ & $\begin{array}{c}0.355 \\
(0.349)\end{array}$ & $\begin{array}{c}4.541^{* * *} \\
(5.204)\end{array}$ & $\begin{array}{c}3.534 * * \\
(2.573)\end{array}$ & $\begin{array}{c}5.369 * * * \\
(9.102)\end{array}$ & $\begin{array}{c}6.908^{* *} \\
(2.526)\end{array}$ \\
\hline Surprise*(BankDebt/At)*Fin. Constraint Measure & $\begin{array}{l}-7.321^{*} \\
(-1.858)\end{array}$ & $\begin{array}{c}-4.282 \\
(-0.628)\end{array}$ & $\begin{array}{c}-12.371^{*} \\
(-1.657)\end{array}$ & $\begin{array}{c}-9.389 \\
(-0.904)\end{array}$ & $\begin{array}{c}-3.809 \\
(-0.626)\end{array}$ & $\begin{array}{c}-2.884 \\
(-0.370)\end{array}$ \\
\hline Firm Controls & NO & YES & NO & YES & NO & YES \\
\hline Industry FE & NO & YES & NO & YES & NO & YES \\
\hline Year FE & NO & YES & NO & YES & NO & YES \\
\hline Industry*Event Clustering & NO & YES & NO & YES & NO & YES \\
\hline Observations & 97,660 & 97,250 & 23,335 & 23,222 & 48,220 & 48,020 \\
\hline
\end{tabular}

This table examines how the effect of monetary policy on firm stock prices varies with their exposure to bank debt and their level of financial constraints. Financial constraints are proxied with the firm's credit rating, size and age. The financial constraint measure takes value 1 if the firm has no rating ( 0 if it is rated) in columns 1 and 2, takes value 1 if the firm is in the bottom quartile of age ( 0 if the firm is in the top quartile) in columns 3 and 4 , and takes value 1 if the firm is in the bottom quartile of size ( 0 if the firm is in the top quartile) in columns 5 and 6 . A constant, non-interacted terms, and the interest rate surprise interacted with book leverage, profitability and the market-to-book ratio are included but not reported. All firm characteristics are lagged by one year and winsorized at the $1 \%$ level. Industries are defined according to the Fama French 48 sector grouping. Parentheses contain t-statistics. The asterisks denote $* * *$ for $\mathrm{p}<0.01$, $* *$ for $\mathrm{p}<0.05$, * for $\mathrm{p}<0.1$. 
Table VI

The Financial Health of Lenders

\begin{tabular}{|c|c|c|c|}
\hline & (1) & (2) & (3) \\
\hline & No Controls & Controls & $\begin{array}{c}\text { Clustering, } \\
\text { Interacted Ind. FE }\end{array}$ \\
\hline \multicolumn{4}{|l|}{ Panel A: Lender Size } \\
\hline Surprise & $\begin{array}{c}-3.268 * * * \\
(-6.116)\end{array}$ & $\begin{array}{c}-2.720 * * * \\
(-4.691)\end{array}$ & $\begin{array}{c}-4.994 \\
(-0.664)\end{array}$ \\
\hline Surprise*(BankDebt/At) & $\begin{array}{l}-7.812^{*} \\
(-1.792)\end{array}$ & $\begin{array}{c}-15.01^{* * *} \\
(-3.059)\end{array}$ & $\begin{array}{l}-13.07 * * \\
(-2.469)\end{array}$ \\
\hline Surprise*Lender Size & $\begin{array}{c}-7.274 * * * \\
(-9.826)\end{array}$ & $\begin{array}{c}-6.315^{* * *} \\
(-6.590)\end{array}$ & $\begin{array}{c}-6.450 * * * \\
(-3.710)\end{array}$ \\
\hline Surprise*(BankDebt/At)*Lender Size & $\begin{array}{l}12.79 * * \\
(2.092)\end{array}$ & $\begin{array}{l}18.30^{* *} \\
(2.565)\end{array}$ & $\begin{array}{l}15.04 * * \\
(1.999)\end{array}$ \\
\hline $\begin{array}{l}\text { Observations } \\
\text { Number of gvkey }\end{array}$ & $\begin{array}{c}29,722 \\
1,551\end{array}$ & $\begin{array}{c}29,678 \\
1,550\end{array}$ & $\begin{array}{c}28,697 \\
1,524\end{array}$ \\
\hline \multicolumn{4}{|l|}{ Panel B: Lender Tier 1 Capital Ratio } \\
\hline Surprise & $\begin{array}{c}1.635^{* * *} \\
(3.306)\end{array}$ & $\begin{array}{c}1.806^{* * *} \\
(3.254)\end{array}$ & $\begin{array}{c}-1.862 \\
(-0.293)\end{array}$ \\
\hline Surprise*(BankDebt/At) & $\begin{array}{l}-7.760^{*} \\
(-1.865)\end{array}$ & $\begin{array}{c}-11.37 * * \\
(-2.280)\end{array}$ & $\begin{array}{l}-9.149 * \\
(-1.691)\end{array}$ \\
\hline Surprise*Tier 1 Cap & $\begin{array}{c}-12.84^{* * *} \\
(-17.88)\end{array}$ & $\begin{array}{c}-11.54 * * * \\
(-13.29)\end{array}$ & $\begin{array}{c}-12.05^{* * *} \\
(-8.248)\end{array}$ \\
\hline Surprise*(BankDebt/At)*Tier 1 Cap & $\begin{array}{l}12.40 * * \\
(2.075)\end{array}$ & $\begin{array}{c}8.402 \\
(1.181)\end{array}$ & $\begin{array}{l}8.244 \\
(0.926)\end{array}$ \\
\hline $\begin{array}{l}\text { Observations } \\
\text { Number of gvkey }\end{array}$ & $\begin{array}{c}29,980 \\
1,883\end{array}$ & $\begin{array}{c}29,903 \\
1,880\end{array}$ & $\begin{array}{c}28,999 \\
1,842\end{array}$ \\
\hline Firm Controls & NO & YES & YES \\
\hline Interacted Firm Controls & NO & YES & YES \\
\hline Industry FE & NO & NO & YES \\
\hline Interacted Industry FE & NO & NO & YES \\
\hline Clustering Fed Date/Industry Level & NO & NO & YES \\
\hline
\end{tabular}

This table examines the role of a lender's financial health on the relation between bank dependence and the sensitivity of prices to monetary policy surprises. Lender financial health is measured as: lender size (logarithm of lender assets), and Tier 1 capital ratio. For each health measure we introduce a dummy which takes value 1 for values in the top quartile, and zero for values in the bottom quartile. BankDebt/At is defined as bank debt (term loans plus drawn revolving credit) over book value of assets. We only report "Surprise and the terms interacted with "Surprise". All regressions also include (unreported) a constant term, as well as ln(assets), book leverage, profitability, market-tobook and interest rate sensitivity. All firm and lender characteristics are lagged by one year and winsorized at $1 \%$. Parentheses contain t-statistics. The asterisks denote $* * *$ for $\mathrm{p}<0.01$, ** for $\mathrm{p}<0.05$, $*$ for $\mathrm{p}<0.1$. 
Table VII

Lender Financial Health, Bank Dependence and Financial Constraints

\begin{tabular}{|c|c|c|c|c|}
\hline & (1) & $(2)$ & (3) & (4) \\
\hline & Unrated & Rated & Young & Old \\
\hline \multicolumn{5}{|l|}{ Panel A: Lender Size } \\
\hline Surprise & $\begin{array}{c}-2.695 \\
(-0.327)\end{array}$ & $\begin{array}{c}-8.005 \\
(-1.105)\end{array}$ & $\begin{array}{l}-17.90 * \\
(-1.877)\end{array}$ & $\begin{array}{c}3.513 \\
(0.516)\end{array}$ \\
\hline Surprise*(BankDebt/At) & $\begin{array}{l}-20.69 * * \\
(-2.553)\end{array}$ & $\begin{array}{c}0.445 \\
(0.0640)\end{array}$ & $\begin{array}{c}-22.21 \\
(-1.164)\end{array}$ & $\begin{array}{l}18.19 \\
(0.729)\end{array}$ \\
\hline Surprise*Lender Size & $\begin{array}{c}-6.580^{* * *} \\
(-3.827)\end{array}$ & $\begin{array}{l}-7.076^{* *} \\
(-2.501)\end{array}$ & $\begin{array}{l}-7.753^{*} \\
(-1.717)\end{array}$ & $\begin{array}{c}0.0723 \\
(0.0254)\end{array}$ \\
\hline Surprise*(BankDebt/At)*Lender Size & $\begin{array}{c}42.01 * * * \\
(3.365)\end{array}$ & $\begin{array}{c}-4.312 \\
(-0.428)\end{array}$ & $\begin{array}{l}43.14^{*} \\
(1.689)\end{array}$ & $\begin{array}{c}-27.69 \\
(-0.923)\end{array}$ \\
\hline $\begin{array}{l}\text { Observations } \\
\text { Number of gvkey }\end{array}$ & $\begin{array}{c}15,531 \\
886 \\
\end{array}$ & $\begin{array}{c}12,680 \\
683 \\
\end{array}$ & $\begin{array}{c}2,135 \\
181 \\
\end{array}$ & $\begin{array}{c}4,207 \\
277 \\
\end{array}$ \\
\hline \multicolumn{5}{|l|}{ Panel B: Lender Tier 1 Capital Ratio } \\
\hline Surprise & $\begin{array}{c}7.258 \\
(1.586)\end{array}$ & $\begin{array}{c}-8.575 \\
(-1.090)\end{array}$ & $\begin{array}{c}-4.463 \\
(-0.816)\end{array}$ & $\begin{array}{c}0.280 \\
(0.0521)\end{array}$ \\
\hline Surprise*(BankDebt/At) & $\begin{array}{c}-8.028 \\
(-0.963)\end{array}$ & $\begin{array}{c}-4.507 \\
(-0.562)\end{array}$ & $\begin{array}{c}-6.604 \\
(-0.297)\end{array}$ & $\begin{array}{c}16.32 \\
(0.956)\end{array}$ \\
\hline Surprise*Tier 1 Cap & $\begin{array}{c}-14.40^{* * *} \\
(-8.549)\end{array}$ & $\begin{array}{l}-9.058 * * \\
(-2.555)\end{array}$ & $\begin{array}{l}-6.253 \\
(-1.494)\end{array}$ & $\begin{array}{c}-17.32 * * * \\
(-6.369)\end{array}$ \\
\hline Surprise*(BankDebt/At)*Tier 1 Cap & $\begin{array}{c}17.96 \\
(1.473)\end{array}$ & $\begin{array}{c}-6.761 \\
(-0.592)\end{array}$ & $\begin{array}{c}-33.64 \\
(-1.358)\end{array}$ & $\begin{array}{c}-12.72 \\
(-0.515)\end{array}$ \\
\hline $\begin{array}{l}\text { Observations } \\
\text { Number of gvkey }\end{array}$ & $\begin{array}{c}16,442 \\
1,119\end{array}$ & $\begin{array}{c}12,108 \\
790\end{array}$ & $\begin{array}{c}2,468 \\
251\end{array}$ & $\begin{array}{c}4,118 \\
334\end{array}$ \\
\hline Firm Controls & YES & YES & YES & YES \\
\hline Interacted Firm Controls & YES & YES & YES & YES \\
\hline Industry FE & YES & YES & YES & YES \\
\hline Interacted Industry FE & YES & YES & YES & YES \\
\hline Clustering Fed Date/Industry Level & YES & YES & YES & YES \\
\hline
\end{tabular}

This table examines the role of the interaction between the financial health of lenders and the financial constraints of firms, and how this interaction affects the sensitivity of bank-dependent firms to monetary policy surprises. Lender financial health is measured as: lender size (logarithm of lender assets), and Tier 1 capital ratio. For each health measure we introduce a dummy which takes the value 1 for values in the top quartile, and zero for values in the bottom quartile. BankDebt/At is defined as bank debt (term loans plus drawn revolving credit) over book value of assets. We only report "Surprise and the terms interacted with "Surprise". All regressions also include (unreported) a constant term, as well as $\ln$ (assets), book leverage, profitability, market-to-book and interest rate sensitivity. Small (Large) are those in the bottom (top) size interval. All firm and lender characteristics are lagged by one year and winsorized at $1 \%$. Parentheses contain t-statistics. The asterisks denote $* * *$ for $\mathrm{p}<0.01,{ }^{* *}$ for $\mathrm{p}<0.05$, $*$ for $\mathrm{p}<0.1$. 
Table VIII

Bank Firm Matching Multivariate Analysis

\begin{tabular}{|c|c|c|c|c|c|c|}
\hline & \multicolumn{3}{|c|}{ Dep. Var. = Bank Size } & \multicolumn{3}{|c|}{ Dep. Var. = Capital Ratio } \\
\hline & $(1)$ & $(2)$ & (3) & (4) & (5) & $(6)$ \\
\hline \multirow[t]{2}{*}{ Size } & $-0.001 * * *$ & $-0.001 * * *$ & $-0.001 * * *$ & $-0.004 * * *$ & $-0.004 * * *$ & $-0.003 * * *$ \\
\hline & $(-3.143)$ & $(-3.201)$ & $(-2.753)$ & $(1.709)$ & $(1.826)$ & $(1.681)$ \\
\hline \multirow[t]{2}{*}{ Book Leverage } & $-20.23 * * *$ & $-19.67 * * *$ & $-11.52 * * *$ & -0.107 & -0.0224 & $-0.637 *$ \\
\hline & $(-5.593)$ & $(-5.441)$ & $(-2.819)$ & $(-0.366)$ & $(-0.0767)$ & $(-1.922)$ \\
\hline \multirow[t]{2}{*}{ BankDebt/At } & -18.47 & 26.45 & -14.06 & -2.055 & $-4.988 * * *$ & $-5.644 * * *$ \\
\hline & $(-0.749)$ & $(1.348)$ & $(-0.623)$ & $(-1.034)$ & $(-3.151)$ & $(-3.073)$ \\
\hline \multirow[t]{2}{*}{ Credit Line (dummy) } & $-2.643 *$ & $-2.568 *$ & $-3.037 * *$ & $0.257 * *$ & $0.240 * *$ & 0.196 \\
\hline & $(-1.854)$ & $(-1.801)$ & $(-2.006)$ & $(2.200)$ & $(2.053)$ & $(1.566)$ \\
\hline Age (since IPO) & $\begin{array}{c}11.68^{* * * *} \\
(41.91)\end{array}$ & $\begin{array}{c}11.73 * * * \\
(42.05)\end{array}$ & $\begin{array}{c}12.29 * * * \\
(40.94)\end{array}$ & $\begin{array}{l}-0.0322 \\
(-1.512)\end{array}$ & $\begin{array}{c}-0.0403^{*} \\
(-1.890)\end{array}$ & $\begin{array}{c}-0.0983^{* * *} \\
(-4.249)\end{array}$ \\
\hline Rated (dummy) & $\begin{array}{c}17.37 * * * \\
(6.644)\end{array}$ & $\begin{array}{c}17.73 * * * \\
(6.797)\end{array}$ & $\begin{array}{c}13.78 * * * \\
(4.774)\end{array}$ & $\begin{array}{l}-0.0724 \\
(-0.349)\end{array}$ & $\begin{array}{c}-0.138 \\
(-0.667)\end{array}$ & $\begin{array}{c}0.138 \\
(0.598)\end{array}$ \\
\hline Profitability & $\begin{array}{c}1.808 \\
(0.226)\end{array}$ & $\begin{array}{c}0.743 \\
(0.0931)\end{array}$ & $\begin{array}{c}-5.834 \\
(-0.667)\end{array}$ & $\begin{array}{c}-2.591^{* * *} \\
(-4.043)\end{array}$ & $\begin{array}{c}-2.532^{* * *} \\
(-3.956)\end{array}$ & $\begin{array}{c}-1.831 * * * \\
(-2.589)\end{array}$ \\
\hline $\mathrm{M} / \mathrm{B}$ & $\begin{array}{l}1.692 * * \\
(2.520)\end{array}$ & $\begin{array}{l}1.580 * * \\
(2.353)\end{array}$ & $\begin{array}{c}2.170 * * * \\
(2.955)\end{array}$ & $\begin{array}{l}0.0337 \\
(0.615)\end{array}$ & $\begin{array}{l}0.0564 \\
(1.028)\end{array}$ & $\begin{array}{c}0.147^{* *} \\
(2.433)\end{array}$ \\
\hline Cash/At & $\begin{array}{c}-25.49 * * * \\
(-4.147)\end{array}$ & $\begin{array}{c}-26.73 * * * \\
(-4.372)\end{array}$ & $\begin{array}{c}-21.93^{* * *} \\
(-3.300)\end{array}$ & $\begin{array}{c}0.239 \\
(0.485)\end{array}$ & $\begin{array}{c}0.280 \\
(0.573)\end{array}$ & $\begin{array}{c}-1.723 * * * \\
(-3.222)\end{array}$ \\
\hline Tangibility & $\begin{array}{c}-29.36 * * * \\
(-3.511)\end{array}$ & $\begin{array}{c}-29.93 * * * \\
(-3.584)\end{array}$ & $\begin{array}{c}-30.79 * * * \\
(-3.417)\end{array}$ & $\begin{array}{c}0.00574 \\
(0.00978)\end{array}$ & $\begin{array}{c}0.169 \\
(0.288)\end{array}$ & $\begin{array}{c}0.0586 \\
(0.0922)\end{array}$ \\
\hline \multicolumn{7}{|l|}{ Risk Measures: } \\
\hline Cash-Flow Volatility & $\begin{array}{c}633.0 \\
(0.811)\end{array}$ & & & $\begin{array}{c}-38.16 \\
(-0.918)\end{array}$ & & \\
\hline Interest Rate Sensitivity & & $\begin{array}{c}-32.71 * * \\
(-2.125)\end{array}$ & & & $\begin{array}{c}2.523^{* * *} \\
(3.110)\end{array}$ & \\
\hline Beta & & & $\begin{array}{c}-0.708 \\
(-1.522)\end{array}$ & & & $\begin{array}{c}-0.101^{* * *} \\
(-2.606)\end{array}$ \\
\hline \multicolumn{7}{|l|}{ Interaction terms: } \\
\hline Cash-Flow Volatility* BankDebt/At & $\begin{array}{c}5,022 * * * \\
(3.308)\end{array}$ & & & $\begin{array}{c}-118.1 \\
(-0.969)\end{array}$ & & \\
\hline Interest-Rate Sensitivity* BankDebt/At & & $\begin{array}{c}-34.37 \\
(-1.444)\end{array}$ & & & $\begin{array}{c}-9.888 * * * \\
(-5.155)\end{array}$ & \\
\hline Beta* BankDebt/At & & & $\begin{array}{c}4.257 \\
(1.211)\end{array}$ & & & $\begin{array}{c}-1.233 * * * \\
(-4.193)\end{array}$ \\
\hline Observations & 29,224 & 29,224 & 25,902 & 29,224 & 29,224 & 25,902 \\
\hline $\begin{array}{l}\text { This table examines bank-firm matching } \\
\text { health, proxied by bank size and Tier } 1 \\
\text { rate sensitivity, and CAPM beta. It also a } \\
\text { with the degree of bank dependence of } \mathrm{f} \\
\text { characteristics interacted with BankDebt } \\
\text { denote } * * * \text { for } \mathrm{p}<0.01 \text {, ** for } \mathrm{p}<0.05 \text {, * } \mathrm{f}\end{array}$ & $\begin{array}{l}\text { ultivariate } \\
\text { ratio, and } f \\
\text { s how the a } \\
\text { 3ank charac } \\
\text { e included }\end{array}$ & $\begin{array}{l}\text { setup by dis } \\
\text { firm risk cha } \\
\text { association b } \\
\text { cteristics, inc } \\
\text { but not repc }\end{array}$ & $\begin{array}{l}\text { playing the } \\
\text { Iracteristics, } \\
\text { etween risk } \\
\text { cluding depo } \\
\text { orted. Paren }\end{array}$ & $\begin{array}{l}\text { ociation b } \\
\text { xied by c } \\
\text { aracteristi } \\
\text { ratio and } \\
\text { ses contai }\end{array}$ & $\begin{array}{l}\text { een the le } \\
\text {-flow vola } \\
\text { nd bank h } \\
\text { idity ratio } \\
\text { statistics. }\end{array}$ & $\begin{array}{l}\text { er financial } \\
\text { ity, interest } \\
\text { lth changes } \\
\text { and all firm } \\
\text { he asterisks }\end{array}$ \\
\hline
\end{tabular}


Table IX

Lender Financial Health and Bank Dependence: Instrumental Variables Estimation

(2)

Bank Health = Bank Size

Bank Health = Capital Ratio

\begin{tabular}{lcc} 
Surprise & $28.16^{* * *}$ & $27.08^{*}$ \\
& $(3.213)$ & $(1.823)$ \\
Surprise*(BankDebt/At) & -78.84 & $-268.8^{* *}$ \\
& $(-1.544)$ & $(-2.231)$ \\
Surprise*Bank Health & $-68.85^{* * *}$ & $-52.59^{*}$ \\
& $(-4.645)$ & $(-1.722)$ \\
Surprise*(BankDebt/At)*Bank Health & $164.3^{*}$ & $522.7^{* *}$ \\
& $(1.672)$ & $(2.173)$ \\
Observations & & 28,125 \\
Number of gvkey & 15,269 & 1,785 \\
\hline Firm Controls & 852 & YES \\
Surprise*Firm Controls & YES & YES \\
Industry FE & YES & YES \\
Interacted Industry FE & YES & YES \\
\hline
\end{tabular}

This table examines the role of a lender's financial health on the effect of bank dependence on the response of firms to monetary policy surprises using instrumental variables (IV) estimation. Lender financial health is measured in two different ways: lender size (logarithm of lender assets), and Tier 1 capital ratio. Lender size is instrumented using the median bank size in the Metropolitan Statistical Area (MSA) or rural county in which the firm is located (Inmsa_p50), and Tier 1 capital ratio is instrumented using the corporate income tax rate in the state in which the firm is located (tax). Column displays the results of an IV regression in which the double interaction term Surprise*Lender Size is instrumented using Surprise*Inmsa_p50, and the triple interaction term Surprise*(BankDebt/At)*( Lender Size) is instrumented using Surprise*(BankDebt/At)*Inmsa_p50. Column2 refers to an IV regression in which the double interaction term Surprise*(Capital Ratio) is instrumented for using Surprise*tax, and the triple interaction term Surprise*(BankDebt/At)*(Capital Ratio) is instrumented using Surprise*(BankDebt/At)*tax. BankDebt/At is defined as bank debt (term loans plus drawn revolving credit) over book value of assets. All regressions also include (unreported) a constant term, as well as $\ln$ (assets), book leverage, profitability, market-to-book, also interacted with Surprise. All firm and lender characteristics are lagged by one year and winsorized at $1 \%$. Parentheses contain tstatistics. The asterisks denote $* * *$ for $\mathrm{p}<0.01$, $* *$ for $\mathrm{p}<0.05$, $*$ for $\mathrm{p}<0.1$. 
Table X

The Role of Hedging Floating Interest Rate Risk

Panel A: Hedgers versus non Hedgers

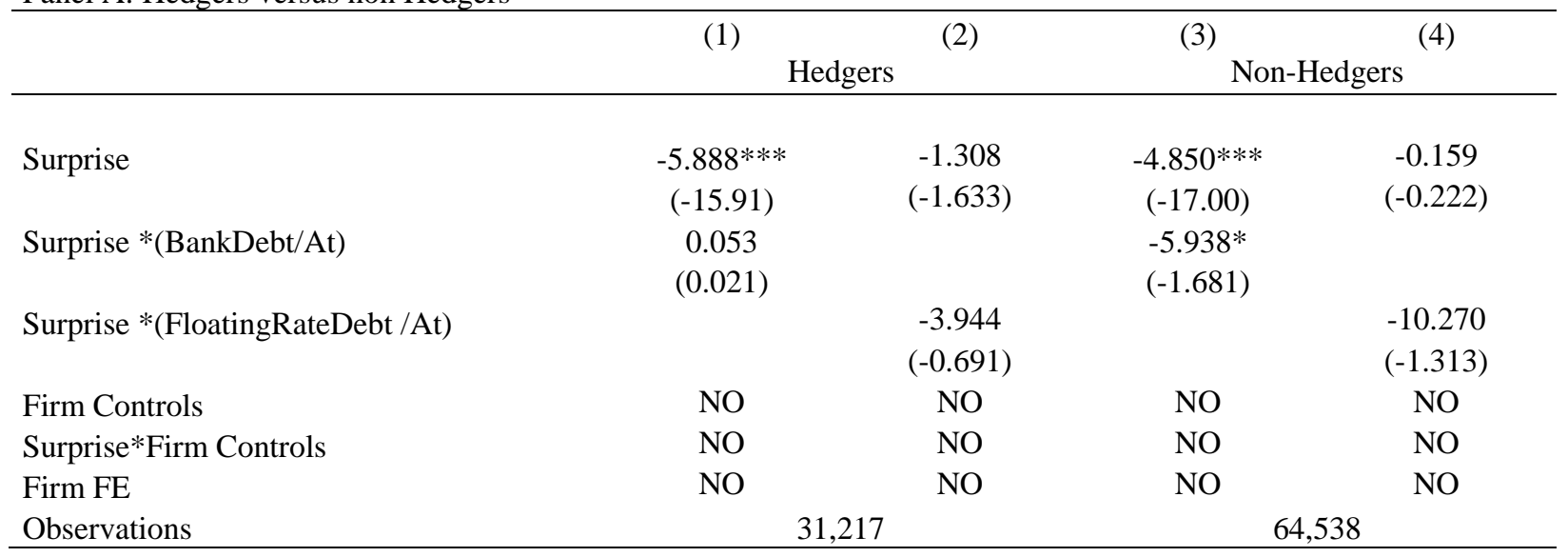

$\underline{\text { Panel B: Financial Constraints }}$

(1) (2) (3) (4)

\begin{tabular}{lcccc} 
& \multicolumn{3}{c}{ Measure of Financial Constraints } \\
\hline & & Unrated & Small & Young \\
\cline { 2 - 4 } Surprise & $-5.093^{* * *}$ & $-5.256^{* * *}$ & $-6.470^{* * *}$ & $-5.243^{* * *}$ \\
& $(-17.71)$ & $(-8.980)$ & $(-17.60)$ & $(-11.71)$ \\
Surprise *(BankDebt/At) & $-12.54^{* * *}$ & $-10.76^{* *}$ & $-17.70^{* * *}$ & $-14.46^{* * *}$ \\
& $(-3.475)$ & $(-2.158)$ & $(-4.274)$ & $(-2.682)$ \\
Surprise * Hedging & -0.0815 & 0.128 & -0.0715 & -0.828 \\
& $(-0.154)$ & $(0.238)$ & $(-0.135)$ & $(-1.026)$ \\
Surprise *(BankD/At)*Hedging & $7.314^{*}$ & 7.439 & $12.36 * * *$ & $10.56^{*}$ \\
Surprise *(BankD/At)*Financial Constraint & $(1.674)$ & $(1.602)$ & $(2.677)$ & $(1.725)$ \\
& & -0.809 & $12.85^{* *}$ & -4.187 \\
Surprise *Financial Constraint & & $(-0.179)$ & $(2.467)$ & $(-0.718)$ \\
Firm Controls & & 0.125 & $4.231^{* * *}$ & $2.697^{* * *}$ \\
Surprise*Firm Controls & & $(0.178)$ & $(5.969)$ & $(3.628)$ \\
Firm FE & YES & YES & YES & YES \\
Observations & YES & YES & YES & YES \\
\hline
\end{tabular}

This table examines how the effect of monetary policy on firm stock prices varies with their hedging activity. Hedgers are defined as those firms that report having hedged their interest rate risk from floating to fixed in their 10-K annual reports. Bank Debt/At is defined as bank debt (term loans plus drawn revolving credit) over book value of assets (At). All regressions include (unreported) a constant term. In Panel A the first two columns only contain firms that hedge, while columns 3-4 contain firms that do not hedge. Unrated is based on S\&P ratings. Small is a dummy for the smallest size tercile. Young is a dummy for the smallest tercile of age, computed as number of years since IPO. All firm and lender characteristics are lagged by one year and winsorized at $1 \%$. Parentheses contain t-statistics. The asterisks denote $* * *$ for $\mathrm{p}<0.01$, ** for $\mathrm{p}<0.05$, * for $\mathrm{p}<0.1$. 
Table XI

The Effect of Monetary Policy on the Cost of Debt

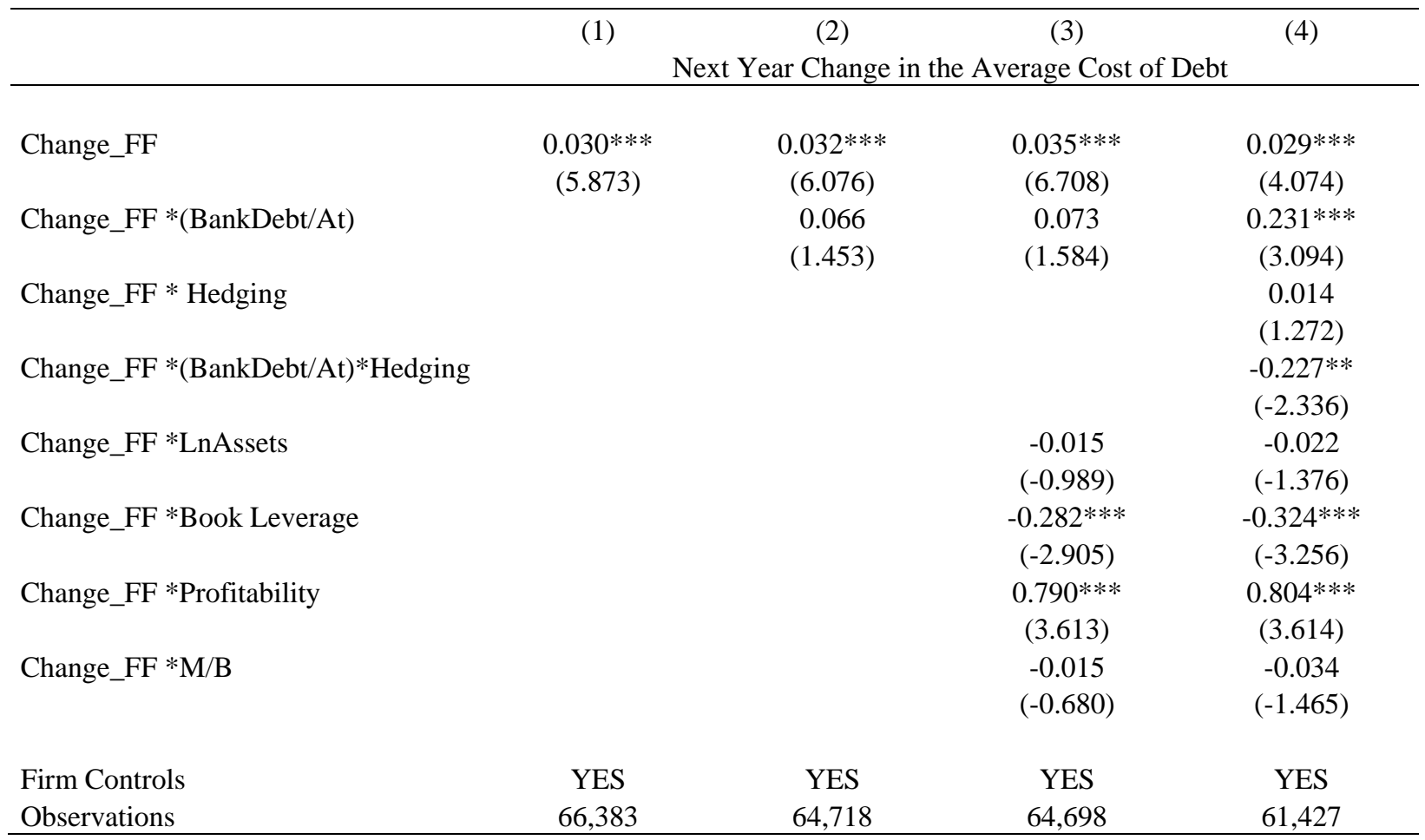

This table examines how monetary policy affects firm cost of debt and how this effect varies with bank dependence and hedging activity. The average cost of debt is computed as the ratio of interest expenses over total debt of the previous year. The change in the average cost of debt is computed as the difference year on year. Change_FF is the change in federal funds rate. Hedgers are defined as those firms that report having hedged their interest rate risk from floating to fixed in their $10 \mathrm{~K}$ annual reports. Bank Debt/At is defined as bank debt (term loans plus drawn revolving credit) over book value of assets (At). All regressions also include (unreported) a constant term. Unreported controls include uninteracted ln(assets), book leverage, market-to-book and profitability, as well as the lower interaction term between Bank Debt/At and hedging. All firm characteristics are lagged by one year and winsorized at $1 \%$. Parentheses contain t-statistics. The asterisks denote $* * *$ for $\mathrm{p}<0.01, * *$ for $\mathrm{p}<0.05$, * for $\mathrm{p}<0.1$. 
TABLES FOR APPENDIX 
Table A1

Description of Firm Level Variables

Item numbers are from Compustat. CIQ items come from Capital IQ.

\begin{tabular}{|c|c|}
\hline Variable & Construction \\
\hline Average Cost of Debt & Interest Expenses (15)/Previous Year Total Debt \\
\hline Bank Debt 1 & [Drawn Credit Lines (CIQ) + Term Loans (CIQ)] / Assets (6) \\
\hline Bank Debt 2 & $\begin{array}{l}\text { [Drawn Credit Lines (CIQ) + Term Loans (CIQ) + Undrawn Credit Lines (CIQ)]/ } \\
\text { Assets (6) }\end{array}$ \\
\hline Book Leverage & (Total Debt) / (Total Debt + Book Value of Equity) \\
\hline Book Value of Equity & Common/Ordinary Equity - Total (60) \\
\hline Drawn Credit Lines/Assets & Drawn Credit Lines (CIQ) / Total Assets (6) \\
\hline Floating Interest Rate Debt & Debt with floating interest rate (CIQ) \\
\hline Hedging Dummy & $\begin{array}{l}\text { A dummy variable that takes the value } 1 \text { if a firms reports floating-to-fixed } \\
\text { interest-rate hedging activities in its } 10-\mathrm{K}\end{array}$ \\
\hline Interest Rate Sensitivity & $\begin{array}{l}\text { Correlation between quarterly firm EBITDA and three-month average LIBOR } \\
\text { rates }\end{array}$ \\
\hline $\mathrm{M} / \mathrm{B}$ & $\begin{array}{l}\text { [Market Value of Equity + Total Debt + Preferred Stock Liquidating Value (10)] / } \\
\text { Total Assets (6) }\end{array}$ \\
\hline Market Value of Equity & Stock Price (199) × Common Shares Used to Calculate EPS (54) \\
\hline Profitability & Operating Income before Depreciation (13) / Total Assets (6) \\
\hline Rated & $\begin{array}{l}\text { A dummy variable that takes the value of one if the firm is rated by the S\&P, and } \\
\text { zero otherwise }\end{array}$ \\
\hline Short-Term Debt & $\begin{array}{l}\text { Debt in current liabilities (34) and is equal to the total amount of short-term notes } \\
\text { and the current portion of long-term debt that is due in one year. More precisely, } \\
\text { short-term debt includes: } 1 \text {. Bank acceptances and overdrafts; } 2 \text {. Brokerage } \\
\text { companies' drafts payable commercial paper; } 3 \text {. Construction loans; } 4 \text {. Current } \\
\text { portion of long-term debt; } 5 \text {. Debt in default; } 6 \text {. Debt due on demand; } 7 \text {. Due to } \\
\text { factor if "interest bearing”; } 8 \text {. Installments on a loan; } 9 \text {. Interest payable when } \\
\text { combined with notes payable; } 10 \text {. Line of credit; } 11 \text {. Loans payable to officers of } \\
\text { the company; 12. Loans payable to parents, and consolidated or unconsolidated } \\
\text { subsidiaries; 13. Loans payable to stockholders } 14 \text {. Notes payable to banks and } \\
\text { others; } 15 \text {. Notes payable that are included in accounts payable, unless specifically } \\
\text { trade notes payable; } 16 \text {. Sinking fund payments. }\end{array}$ \\
\hline Size (At) & Logarithm of Book Value of Total Assets (6) , deflated to base year 2000 \\
\hline Term Loans /Assets & Term Loans (CIQ)/ Total Assets (6) \\
\hline Total Debt & Long-Term Debt (9) + Debt in Current Liabilities (34) \\
\hline Total Debt & Debt in Current Liabilities (34) + Long-Term Debt (9) \\
\hline Undrawn Credit Lines / Assets & Undrawn Credit Lines (CIQ) / Total Assets (6) \\
\hline
\end{tabular}


Table A2

The Sign of Controls Across Different Sample Periods

\begin{tabular}{lccccc}
\hline & $(1)$ & $(2)$ & $(3)$ & $(4)$ & $(5)$ \\
& $1989-2008$ & $1989-1994$ & $1994-2002$ & $1989-2002$ & $2003-2008$ \\
\hline & & & & & \\
& $-5.125 * *$ & -2.432 & $-7.438^{* *}$ & $-4.925^{* *}$ & $-8.250^{* * *}$ \\
Surprise & $(-2.309)$ & $(-0.978)$ & $(-2.553)$ & $(-2.071)$ & $(-3.710)$ \\
Surprise*LnAssets & $-0.561^{*}$ & -0.304 & -0.0930 & -0.410 & $-1.116^{* * *}$ \\
& $(-1.884)$ & $(-0.885)$ & $(-0.162)$ & $(-1.210)$ & $(-2.859)$ \\
Surprise*Book Leverage & 0.730 & $-1.812^{*}$ & 1.044 & 0.361 & 1.557 \\
& $(0.661)$ & $(-1.935)$ & $(0.469)$ & $(0.301)$ & $(0.627)$ \\
Surprise*Profitability & 4.457 & 1.564 & 11.37 & 7.042 & $-16.26^{* *}$ \\
& $(1.057)$ & $(0.586)$ & $(1.407)$ & $(1.455)$ & $(-2.460)$ \\
Surprise*M/B & $-2.030^{* * *}$ & -0.557 & $-3.339 * * *$ & $-2.098^{* *}$ & -0.422 \\
& $(-2.680)$ & $(-0.981)$ & $(-2.872)$ & $(-2.562)$ & $(-0.654)$ \\
Year FE & & & & YES \\
Industry FF48 FE & YES & YES & YES & YES & YES \\
Cluster (Fed event*Industry) & YES & YES & YES & YES & YES \\
Observations & YES & YES & YES & YES & YES \\
Number of gvkey & & & & & 101,301 \\
\hline
\end{tabular}

This table examines the subsample-stability of the interaction effects between firm-level controls and monetary policy surprises. A constant and non-interacted coefficients are included but not reported. All firm characteristics are lagged by one year and winsorized at the $1 \%$ level. Standard errors are two-way clustered at the date and industry levels. Industries are defined according to the Fama French 48 sector grouping. Parentheses contain t-statistics. The asterisks denote $* * *$ for $\mathrm{p}<0.01$, ** for $\mathrm{p}<0.05$, $*$ for $\mathrm{p}<0.1$. 
Table A3

Which Firms Use Bank, Floating-Rate and Short-Term Debt, and Interest Rate Hedging

\begin{tabular}{|c|c|c|c|c|c|c|}
\hline & $\begin{array}{c}\text { (1) } \\
\text { Bank/At } \\
\end{array}$ & $\begin{array}{c}\text { (2) } \\
\text { Bank/At } \\
\end{array}$ & $\begin{array}{c}\text { (3) } \\
\text { Bank/At } \\
\end{array}$ & $\begin{array}{c}(4) \\
\text { Floating-Rate } \\
\text { Debt/At }\end{array}$ & $\begin{array}{c}(5) \\
\text { Short-Term } \\
\text { Debt/At } \\
\end{array}$ & $\begin{array}{c}\text { (6) } \\
\text { Hedging } \\
\end{array}$ \\
\hline LnAssets & $\begin{array}{c}-0.0147^{* * *} \\
(-8.219)\end{array}$ & $\begin{array}{c}-0.0151^{* * *} \\
(-8.003)\end{array}$ & $\begin{array}{c}-0.0149 * * * \\
(-8.333)\end{array}$ & $\begin{array}{c}-0.002 * * \\
(-2.017)\end{array}$ & $\begin{array}{c}0.001 * * \\
(2.240)\end{array}$ & $\begin{array}{c}0.177^{* * * *} \\
(8.854)\end{array}$ \\
\hline Profitability & $\begin{array}{c}0.144^{* * *} \\
(7.385)\end{array}$ & $\begin{array}{c}0.140 * * * \\
(6.787)\end{array}$ & $\begin{array}{c}0.133^{* * *} \\
(6.889)\end{array}$ & $\begin{array}{c}0.098 * * * \\
(7.104)\end{array}$ & $\begin{array}{c}-0.002 \\
(-0.437)\end{array}$ & $\begin{array}{c}1.771^{* * *} \\
(7.867)\end{array}$ \\
\hline Market to Book & $\begin{array}{c}-0.0242 * * * \\
(-10.91)\end{array}$ & $\begin{array}{c}-0.0241^{* * *} \\
(-9.994)\end{array}$ & $\begin{array}{c}-0.0221^{* * *} \\
(-10.36)\end{array}$ & $\begin{array}{c}-0.010^{* * *} \\
(-8.610)\end{array}$ & $\begin{array}{c}-0.002 * * * \\
(-4.705)\end{array}$ & $\begin{array}{c}-0.179 * * * \\
(-7.554)\end{array}$ \\
\hline Bank/At & & & & $\begin{array}{c}0.892 * * * \\
(52.10)\end{array}$ & $\begin{array}{c}0.0930 * * * \\
(6.139)\end{array}$ & $\begin{array}{c}2.775^{* * *} \\
(12.84)\end{array}$ \\
\hline Book Leverage & $\begin{array}{c}0.340 * * * \\
(26.17)\end{array}$ & $\begin{array}{c}0.342 * * * \\
(24.98)\end{array}$ & $\begin{array}{c}0.333 * * * \\
(25.63)\end{array}$ & $\begin{array}{c}0.0962 * * * \\
(11.12)\end{array}$ & $\begin{array}{c}0.0702 * * * \\
(12.65)\end{array}$ & $\begin{array}{c}0.626 * * * \\
(6.435)\end{array}$ \\
\hline Unrated & $\begin{array}{c}0.0179 * * \\
(2.353)\end{array}$ & $\begin{array}{c}0.0206 * * * \\
(2.626)\end{array}$ & $\begin{array}{c}0.0196 * * * \\
(2.602)\end{array}$ & $\begin{array}{c}-0.00218 \\
(-0.452)\end{array}$ & $\begin{array}{c}0.00355 \\
(1.204)\end{array}$ & $\begin{array}{c}-0.381 * * * \\
(-5.720)\end{array}$ \\
\hline Interest Rate Sensitivity & $\begin{array}{l}-0.0168 \\
(-1.439)\end{array}$ & & & & & \\
\hline CAPM beta & & $\begin{array}{c}-0.00453^{* * *} \\
(-3.329)\end{array}$ & & & & \\
\hline Cash Flow Volatility & & & $\begin{array}{c}-3.165^{* * * *} \\
(-5.078)\end{array}$ & & & \\
\hline Observations & 99,621 & 89,424 & 99,621 & 98,769 & 99,621 & 93,653 \\
\hline
\end{tabular}

This table examines the use of bank debt, floating-rate debt, short-term debt and interest rate hedging, using firm-year data. A constant is included but not reported. All firm characteristics are winsorized at the $1 \%$ level. Standard errors are clustered at the firm level. Columns 1-3 use a Tobit specification with lower censoring at 0 and upper censoring at 1 , while column 4 is a Probit. Parentheses contain t-statistics. The asterisks denote $* * *$ for $\mathrm{p}<0.01$, ** for $\mathrm{p}<0.05$, * for $\mathrm{p}<0.1$. 


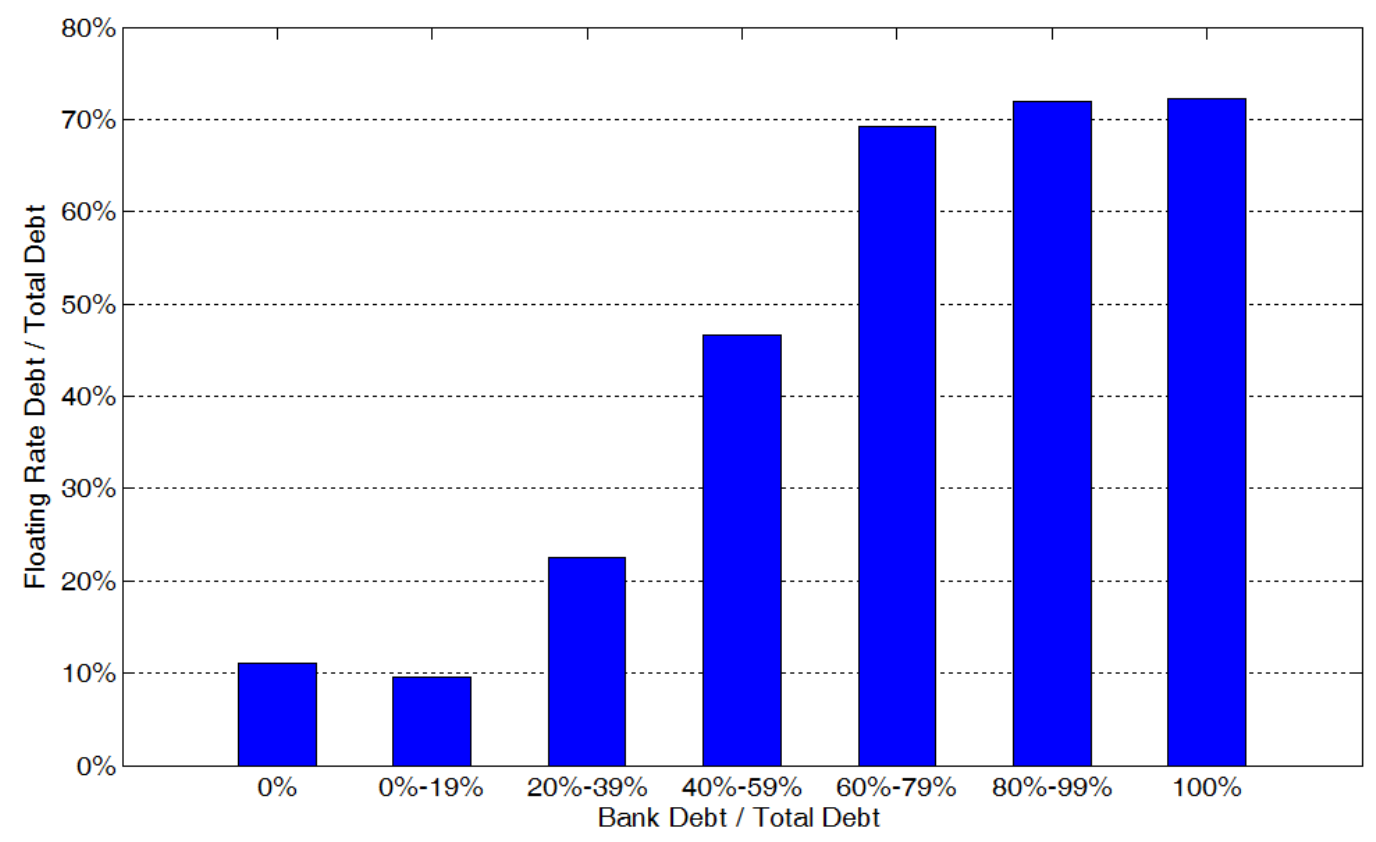

Figure 1

The relation between bank debt and floating-rate debt

This figure displays the relation between bank debt and floating-rate debt as a percentage of a firm's total debt. Firms are grouped in the horizontal axis according to bank debt as a percentage of total debt. The vertical axis shows the corresponding percentages of floating-rate debt as a percentage of total debt. 